Prepared in cooperation with the U.S. Army Corps of Engineers

Flow Characteristics and Salinity Patterns in Tidal Rivers Within the Northern Ten Thousand Islands, Southwest Florida, Water Years 2007-19

Scientific Investigations Report 2021-5028 
Cover. Faka Union Canal looking downstream (to the south). Photograph by Lars Soderqvist, U.S. Geological Survey. 


\section{Flow Characteristics and Salinity Patterns in Tidal Rivers Within the Northern Ten Thousand Islands, Southwest Florida, Water Years 2007-19}

By Amanda C. Booth and Travis M. Knight

Prepared in cooperation with the U.S. Army Corps of Engineers

Scientific Investigations Report 2021-5028 


\section{U.S. Geological Survey, Reston, Virginia: 2021}

For more information on the USGS - the Federal source for science about the Earth, its natural and living resources, natural hazards, and the environment—visit https://www.usgs.gov or call 1-888-ASK-USGS.

For an overview of USGS information products, including maps, imagery, and publications, visit https://store.usgs.gov/.

Any use of trade, firm, or product names is for descriptive purposes only and does not imply endorsement by the U.S. Government.

Although this information product, for the most part, is in the public domain, it also may contain copyrighted materials as noted in the text. Permission to reproduce copyrighted items must be secured from the copyright owner.

Suggested citation:

Booth, A.C., and Knight, T.M., 2021, Flow characteristics and salinity patterns in tidal rivers within the northern Ten Thousand Islands, southwest Florida, water years 2007-19: U.S. Geological Survey Scientific Investigations Report 2021-5028, 21 p., https://doi.org/10.3133/sir20215028.

ISSN 2328-0328 (online) 


\section{Acknowledgments}

This project was partially funded by the Greater Everglades Priority Ecosystems Science (GEPES) Program, which was a part of the Ecosystems Mission Area. The authors wish to thank Michael Simmons with the U.S. Army Corps of Engineers for review of this report. The authors also wish to thank Lars Soderqvist, Drew Milewski, Rachel Margalus, and Megan Montgomery of the U.S. Geological Survey for their many hours of hard work in the field collecting the data presented in this report and for computing and verifying flow and salinity data. 



\section{Contents}

Acknowledgments ……...................................................................................................................

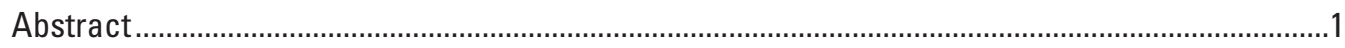

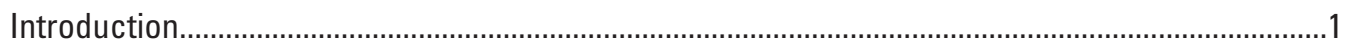

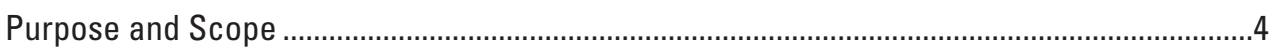

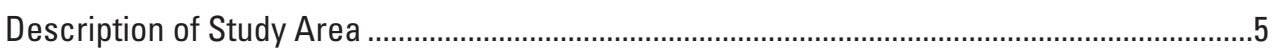

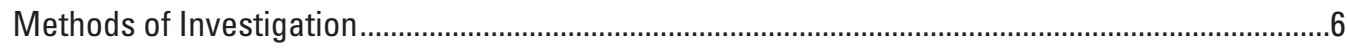

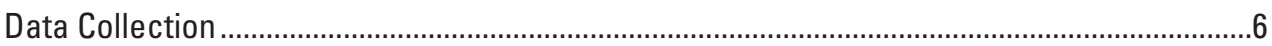

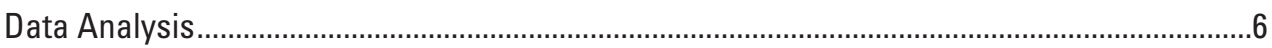

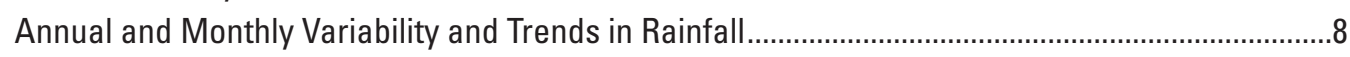

Flow Characteristics and Salinity Patterns in the Ten Thousand Islands ......................................10

Annual and Monthly Flow Characteristics of Tidal Rivers ......................................................10

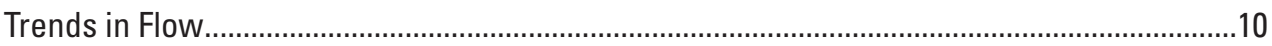

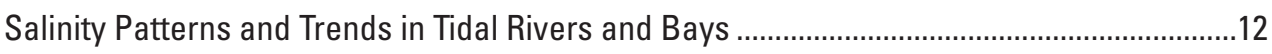

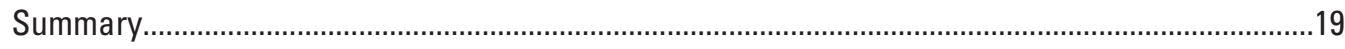

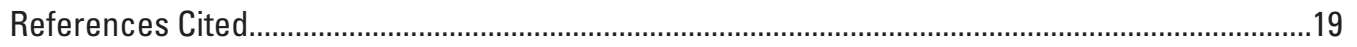

\section{Figures}

1. Map showing the northern Ten Thousand Islands estuary study area.............................2

2. Map showing U.S. Geological Survey streamflow and water-quality stations in the northern Ten Thousand Islands estuary ...................................................................

3. Photograph showing Faka Union weir, September 2009..................................................

4. Photograph showing U.S. Geological Survey streamflow and water-quality station at Faka Union River, June 2018.

5. Graph showing monthly and annual rainfall in the northern Ten Thousand Islands estuary, water years 2007-19, calculated using data obtained from the South Florida Water Management District rainfall stations, Dan House Prairie and Southern Golden Gate Estates.........................................................................

6. Graphs showing annual flow at tidal tributaries, water years 2008 and 2011-19...........11

7. Graph showing flow contributed by Pumpkin River, Faka Union River, and East River, water years 2008, 2011, and 2014-19 and annual rainfall totals at Dan

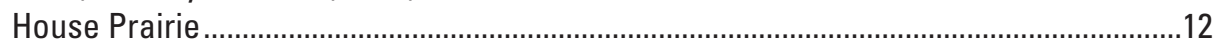

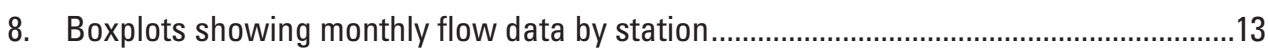

9. Graphs showing monthly rainfall at Dan House Prairie and flow at Pumpkin River, East River, and Faka Union River, water years 2007-19, and monthly rainfall at Dan House Prairie and flow at East River and Pumpkin River.

10. Boxplots showing salinity data by station and water year..............................................16

11. Graph showing monthly mean salinity values by station, July 2006September 2019, Ten Thousand Islands estuary area 


\section{Tables}

1. Monitoring station names, station numbers, periods of water quality and flow record, and percentages of monthly means estimated if insufficient data were collected, northern Ten Thousand Islands estuary, Florida .7

2. Seasonal-Kendall trend analysis for rainfall by station

3. Percentage of total monthly flow that was negative during water years 2008 and 2011-19 in the northern Ten Thousand Islands estuary ............................................15

4. Trend analysis of rainfall-adjusted flow by station

5. Percentage of instantaneous salinity values greater than or equal to 35.0 parts per thousand, water years 2007-08 and 2011-19, in the northern Ten Thousand Islands estuary.

6. Maximum and minimum monthly salinity means, water years $2007-08$ and 2011-19, in the northern Ten Thousand Islands estuary

7. Trend analysis on rainfall-adjusted salinity by station......... 18

\section{Conversion Factors}

U.S. customary units to International System of Units

\begin{tabular}{|c|c|c|}
\hline Multiply & By & To obtain \\
\hline \multicolumn{3}{|c|}{ Length } \\
\hline inch (in.) & 2.54 & centimeter $(\mathrm{cm})$ \\
\hline foot $(\mathrm{ft})$ & 0.3048 & meter $(\mathrm{m})$ \\
\hline mile (mi) & 1.609 & kilometer (km) \\
\hline \multicolumn{3}{|c|}{ Area } \\
\hline square mile $\left(\mathrm{mi}^{2}\right)$ & 2.590 & square kilometer $\left(\mathrm{km}^{2}\right)$ \\
\hline \multicolumn{3}{|c|}{ Volume } \\
\hline acre-foot (acre-ft) & 1,233 & cubic meter $\left(\mathrm{m}^{3}\right)$ \\
\hline \multicolumn{3}{|c|}{ Flow rate } \\
\hline mile per hour $(\mathrm{mi} / \mathrm{h})$ & 1.609 & kilometer per hour $(\mathrm{km} / \mathrm{h})$ \\
\hline cubic foot per second $\left(\mathrm{ft}^{3} / \mathrm{s}\right)$ & 0.02832 & cubic meter per second $\left(\mathrm{m}^{3} / \mathrm{s}\right)$ \\
\hline \multicolumn{3}{|c|}{ Trend analysis slope } \\
\hline cubic foot per second per year $\left(\left[\mathrm{ft}^{3} / \mathrm{s}\right] / \mathrm{yr}\right)$ & 0.02832 & cubic meter per second per year $\left(\left[\mathrm{m}^{3} / \mathrm{s}\right] / \mathrm{yr}\right)$ \\
\hline \multicolumn{3}{|c|}{ Precipitation } \\
\hline inch per year (in/yr) & 2.54 & centimeter per year $(\mathrm{cm} / \mathrm{yr})$ \\
\hline
\end{tabular}

\section{Datum}

Vertical coordinate information is referenced to the National Geodetic Vertical Datum of 1929 (NGVD 29).

Horizontal coordinate information is referenced to the North American Datum of 1983 (NAD 83).

Elevation, as used in this report, refers to distance above the vertical datum. 


\section{Abbreviations}

$\begin{array}{ll}\text { DANHP } & \text { Dan House Prairie rainfall station } \\ \text { FKSTRN } & \text { Fakahatchee Strand North rainfall station } \\ \text { FU4S_S } & \text { Faka Union Canal weir 4 spillway } \\ \text { NWIS } & \text { National Water Information System } \\ \text { ppt } & \text { parts per thousand } \\ \text { SFWMD } & \text { South Florida Water Management District } \\ \text { SGGE } & \text { Southern Golden Gate Estates } \\ \text { SGGEWX } & \text { Southern Golden Gate Estates weather station } \\ \text { TTI } & \text { Ten Thousand Islands } \\ \text { USGS } & \text { U.S. Geological Survey }\end{array}$





\title{
Flow Characteristics and Salinity Patterns in Tidal Rivers Within the Northern Ten Thousand Islands, Southwest Florida, Water Years 2007-19
}

\author{
By Amanda C. Booth and Travis M. Knight
}

\section{Abstract}

Freshwater flow to the Ten Thousand Islands (TTI) estuary has been altered by the construction of the Tamiami Trail and construction of features in the now defunct Southern Golden Gate Estates development. This development included four associated canals that combine into the Faka Union Canal, which discharges into the TTI estuary. The Picayune Strand Restoration Project (PSRP) was initiated in 2007 to improve freshwater delivery to the TTI estuary by removing hundreds of miles of roads, emplacing hundreds of canal plugs, removing exotic vegetation, and constructing three pump stations. Quantifying the tributary flows and salinity patterns prior to, during, and after the restoration is essential to assessing the effectiveness of upstream restoration efforts. The U.S. Geological Survey, in cooperation with U.S. Army Corps of Engineers, initiated an ongoing study in 2006 to assess flow and salinity patterns in the TTI estuary. This is the second report by the U.S. Geological Survey describing flow characteristics and salinity patterns in the TTI area as part of the PSRP. This report describes flow characteristics and salinity patterns for the monitoring stations at Faka Union River, Pumpkin River, and East River and includes an assessment of salinity data from the Faka Union Boundary and Blackwater River water-quality stations for water years 2007-19. A water year is defined as the 12-month period from October 1 for any given year to September 30 of the following year.

Annual and monthly variations in flow and salinity are often related to variations in rainfall with high and low annual flows (and below average and above average salinities) typically occurring during years with high and low annual rainfall, respectively. Monthly flows typically begin increasing in June and peak in September. Over the study period, positive trends in rainfall-adjusted monthly flow were detected at Faka Union River and East River, whereas no significant trend in flow was detected at Pumpkin River. Faka Union River is the largest contributor of freshwater to the TTI estuary, providing over 80 percent of the annual freshwater inflow to the estuary. The Faka Union Canal is expected to be the largest contributor of freshwater because until the PSRP is completed, the Faka Union Canal receives substantial drainage from multiple canals, which is not the case for Pumpkin and East Rivers. East River was the second largest contributor, followed by Pumpkin River. East River is downstream of the Fakahatchee Stand, which is a larger contributing area than the current contributing area for Pumpkin River. Monthly mean salinities were lowest at Faka Union River and East River, indicating that they received a greater amount of freshwater than the stations to the west. Negative trends in rainfall-adjusted salinity monthly means were observed at all monitoring stations during the study period. Increased trends in flow and decreased trends in salinity are attributed to increases in flow from upstream canals.

\section{Introduction}

The Ten Thousand Islands (TTI) estuary of southwest Florida (fig. 1) is part of the largest expanse of mangrove forest in the United States and provides valuable fish and wildlife habitat. The TTI estuary is home to large populations of wading birds including herons, egrets, Platalea ajaja (roseate spoonbills), and Mycteria americana (wood storks). At least 200 species of fish inhabit the area (U.S. Fish and Wildlife Service, 2008). More than 10 percent of the Trichechus manatus latirostris (Florida manatee) population uses the TTI estuary throughout the year (U.S. Fish and Wildlife Service, 2008). The TTI serves as critical habitat, designated essential to the conservation of several threatened or endangered species, including the Florida manatee, the endangered Pristis pectinata (smalltooth sawfish) (Simpfendorfer and others, 2010), and Caretta (loggerhead turtle) (U.S. Army Corps of Engineers, 2020).

The TTI is home to extensive mangrove forests, seagrasses, and oyster reefs, which are all designated essential fish habitat (U.S. Army Corps of Engineers, 2020). Oyster reefs provide habitat for many species, filter nutrients and particulates out of the water column, protect against coastal erosion, sequester carbon, and are sentinels for environmental monitoring (Volety and others, 2014). Oysters tolerate salinities between 0 and 42 parts per thousand (ppt), although the optimal salinities for growth range from 14 to $28 \mathrm{ppt}$ 


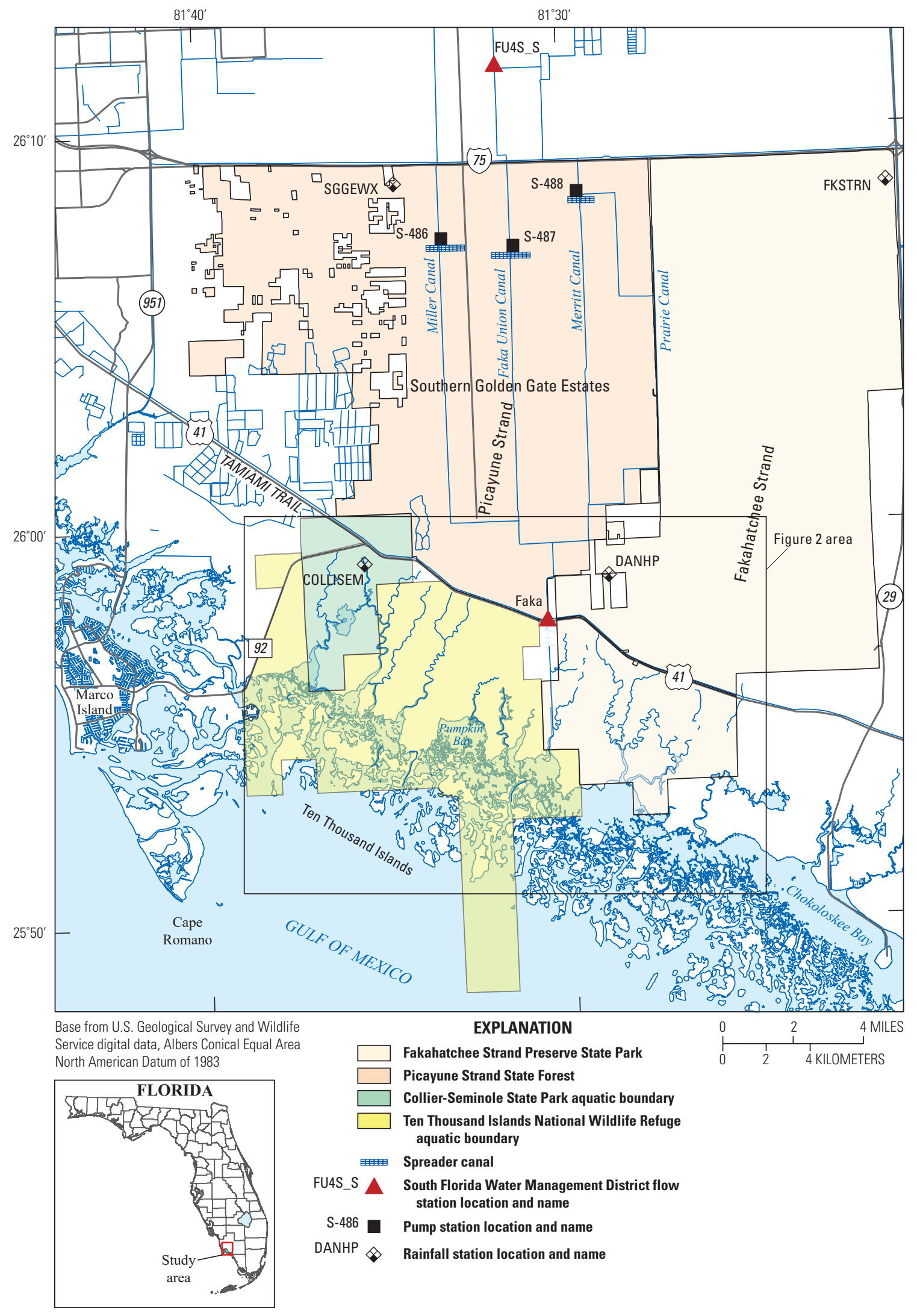

Figure 1. The northern Ten Thousand Islands estuary study area. 
(Shumway, 1996). Periods of increased salinity are known to make oysters more susceptible to disease (Chu and Volety, 1997). Maintaining the optimal salinity range is crucial for maintaining oyster health. The environmental health and ecological functioning of the TTI estuary is dependent upon the quality, quantity, timing, and distribution of freshwater deliveries to the estuary.

Prior to human alteration of the upstream landscape, the TTI estuary received its freshwater from sheet flow from the Fakahatchee Strand and Picayune Strand watersheds through a natural course of sloughs, wetlands, marshes, and rivers. This historical freshwater sheet flow was altered by the construction of U.S. Highway 41 (fig. 1), also known as the Tamiami Trail, and a number of features relating to the development of the once-planned residential community of Southern Golden Gate Estates (SGGE) (Light, 2006). The Tamiami Trail was completed in 1928 (Light 2006), creating a blockage to the natural drainage of the Picayune and Fakahatchee Strands. A borrow canal dug along the north side of the Tamiami Trail conveys water under the road at 35 bridges and 16 culverts between County Road 92 and State Road 29. In 2006, nine new culverts were constructed under the Tamiami Trail to restore sheet flow to the TTI estuary as part of the Tamiami Trail Culverts Project (U.S. Army Corps of Engineers, 2008).

A number of features were constructed during the 1960s as part of the 86-square-mile SGGE development, including the Faka Union Canal System. This system consists of four canals (Miller Canal, Faka Union Canal, Merritt Canal, and Prairie Canal) that were excavated to drain the area for the SGGE development (fig. 1). Several roads, with adjacent drainage ditches, diverted sheet flow into the Faka Union Canal System, accelerating drainage within the watershed and reducing wetland inundation, aquifer recharge, and base flow into the estuaries. The Miller, Merritt, and Prairie Canals ultimately combine with the Faka Union Canal, which flows southward under U.S. Highway 41, the southern boundary of the SGGE. Approximately 48 miles (mi) of canals were created, and $270 \mathrm{mi}$ of roads were constructed, prior to the economic failure of the now defunct SGGE (South Florida Water Management District, 2015); the canals facilitated artificially enhanced drainage and the roads impeded the natural flow patterns within the SGGE. East River (fig. 2) is located downstream of the Fakahatchee Strand and, therefore, is not in the direct area of influence from the SGGE development.

Salinity maps produced by the U.S. Geological Survey (USGS) during 2007-10 documented the patterns of altered freshwater flows to the estuary (Soderqvist and Patino, 2010). During periods of increased rainfall, Faka Union Canal was a point source of high flows of freshwater, as indicated by large freshwater plumes in the estuary. In addition, higher salinities were often observed in the inner bays west of the Faka Union Canal, particularly Pumpkin Bay (fig. 2), compared to the inner bays east of the Faka Union Canal. Areas to the west of Faka Union are more impacted by the drainage features of the SGGE, as compared to areas to the east, which receive flows from the Fakahatchee Strand.
During 2008-10, flows to the estuary were computed by the USGS for all of the bridges and culverts along the Tamiami Trail between County Road 92 and State Road 29 (except for the Faka Union Canal) and by the South Florida Water Management District (SFWMD) at the Faka Union Canal. The Faka Union Canal accounted for more than half of the flow under the Tamiami Trail during this period (58-62 percent, depending on the year). An average of 9 percent of the flow under the Tamiami Trail occurred west of the Faka Union Canal and about a third of the flow occurred east of the Faka Union Canal (Booth and others, 2014).

The goal of the Picayune Strand Restoration Project, a Comprehensive Everglades Restoration Plan authorized by Congress in 2007, is to restore flows and hydroperiods in the wetlands, while reducing freshwater point releases to the estuary and continuing to provide existing levels of flood protection (U.S. Army Corps of Engineers, 2008). The project calls for the removal of $260 \mathrm{mi}$ of roads, the emplacement of 100 plugs within $48 \mathrm{mi}$ of existing canals, the removal of exotic vegetation, and the construction of three pump stations with downstream spreader canals to restore sheet flow through the area while maintaining flood control capacity for communities to the north (U.S. Army Corps of Engineers, 2008).

The SFWMD plugged $7 \mathrm{mi}$ of the Prairie Canal in Fall of 2006 in an effort to expedite restoration efforts (U.S. Army Corps of Engineers, 2008) and removed $65 \mathrm{mi}$ of road adjacent to the canal by the fall of 2007 (Baisden and Starnes, 2019). The roads and logging trams east of the Merritt Canal were degraded or removed from 2006 to 2012. Removal of the roads and logging trams between Merritt and Faka Union Canals began in 2010, and the majority were removed by the end of 2012. Plugging of the Merritt Canal began in the fall of 2014 (Chuirazzi and others, 2015), and $10 \mathrm{mi}$ of the Merritt Canal were plugged by June 2015 (South Florida Water Management District, 2015). The Merritt Pump Station (S-488; fig. 1) was completed in September 2014 and is capable of pumping 810 cubic feet per second $\left(\mathrm{ft}^{3} / \mathrm{s}\right)$ to provide water for restoration efforts and flood control to the north (South Florida Water Management District, 2015). Road removal between Faka Union Canal and Miller Canal began in late 2011, and by mid-2014, the majority of the road removal between these two canals was completed (Chuirazzi and others, 2015). The Faka Union Pump Station (S-487; fig. 1) construction was completed during the summer of 2017 , and this station is capable of pumping $2,650 \mathrm{ft}^{3} / \mathrm{s}$. As part of the S-487 construction project, $12 \mathrm{mi}$ of canal were plugged and $100 \mathrm{mi}$ of roadway were removed (Baisden and Starnes, 2019). The construction of the Miller Canal Pump Station (S-486; fig. 1) was completed in May of 2019. As part of the S-486 construction project, an additional $13 \mathrm{mi}$ of canal were plugged and $65 \mathrm{mi}$ of roadway were removed (Baisden and Starnes, 2019). The Faka Union and Miller canal pump stations are fully operational (as of 2017 and 2019, respectively); however, they are only operated during emergency events or for testing until the future southwest protection feature levee is completed (M. Simmons, U.S. Army Corps of Engineers, oral 


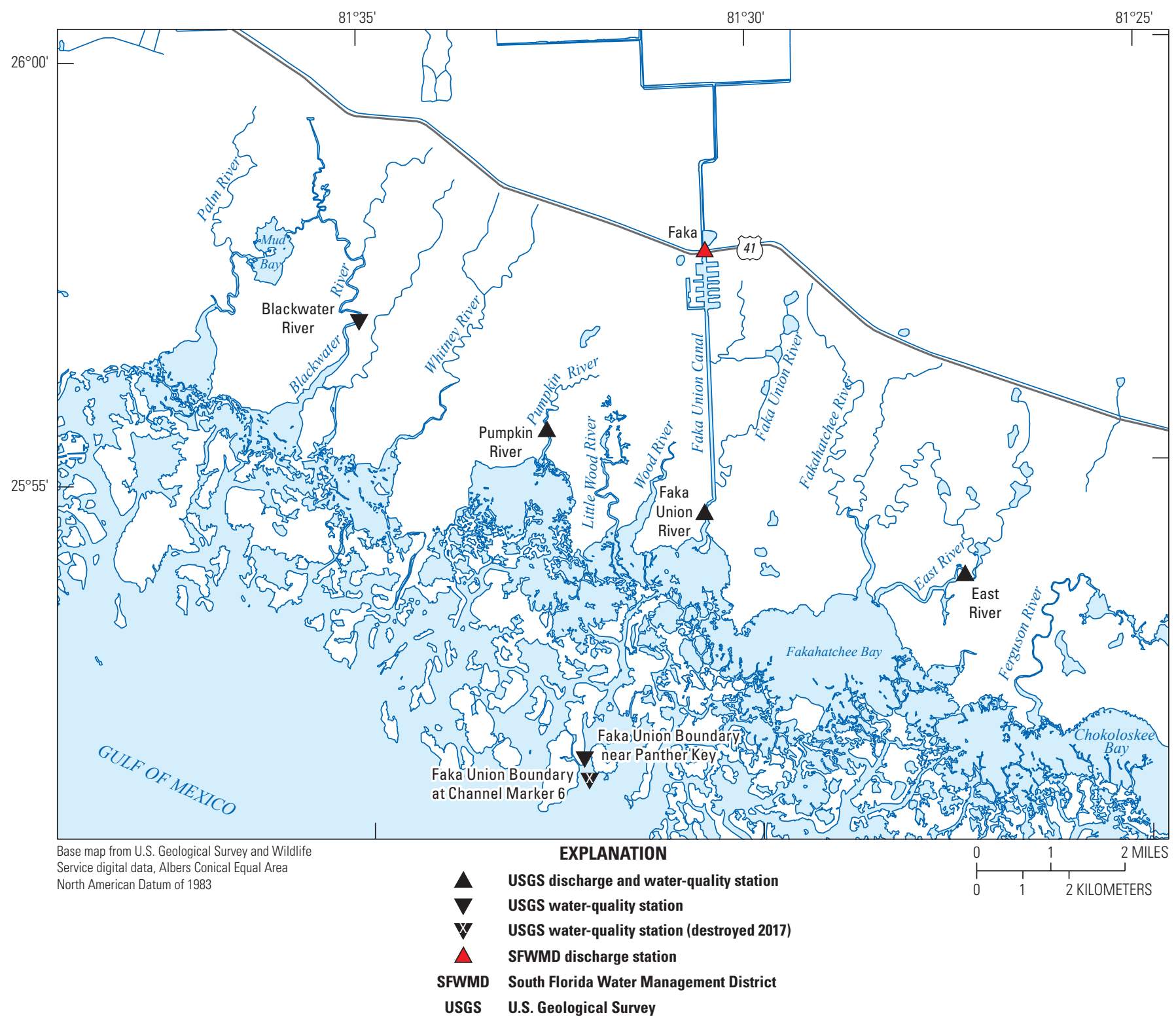

Figure 2. U.S. Geological Survey streamflow and water-quality stations in the northern Ten Thousand Islands estuary.

commun., 2020). Future Picayune Strand Restoration Project work will include construction of the southwest protection feature levee to provide flood risk protection for the agricultural lands to the southwest of the project (projected start 2021). Miller Boulevard and Tram Road are anticipated to be removed by 2022. The east-west "stair-step" canal and the Faka Union Canal are anticipated to be plugged in 2021 and the Miller Canal will be plugged after the completion of the southwest protection feature (M. Simmons, U.S. Army Corps of Engineers, oral commun., 2020).

Quantifying the tributary flows and salinity patterns in the TTI estuary before and after the restoration measures just described is essential to accurately assess the effectiveness of restoration efforts. To address this need, the USGS initiated a study in 2006 to monitor flow and salinity in the TTI estuary.
This ongoing study is in cooperation with the U.S. Army Corps of Engineers and was conducted as part of the Greater Everglades Priority Ecosystems Science Program.

\section{Purpose and Scope}

The purpose of this report is to describe the flow characteristics and salinity patterns within the northern parts of the TTI estuary between water year 2007 and 2019, a period when many restoration activities occurred in the watershed. This report expands upon the findings of a preceding report (Booth, 2016) that assessed flow characteristics and salinity patterns in the study area between 2007 and 2014. Blackwater River flow data collection was discontinued in 2015 and therefore, data for this site were not included in this analysis. All 
data presented within this report are grouped by water year, which is defined as October 1 of the previous calendar year to September 30 of the current calendar year. For example, water year 2019 is from October 1, 2018, to September 30, 2019.

This report focuses on flow and salinity in tidal rivers within the TTI National Wildlife Refuge and Collier-Seminole State Park (fig. 1) and on how both variables are affected by upland restoration activities. Flow and salinity data (the latter computed from continuous specific conductance measurements as described by Wagner and others [2006]) are presented and discussed for three USGS stations on the Faka Union River, Pumpkin River, and East River (fig. 2). Salinity data are also presented and discussed for two additional USGS stations, Blackwater River and Faka Union Boundary (fig. 2). Additional flow data are presented and discussed for SFWMD stations on Faka Union Canal and the Faka Union Canal weir 4 spillway (Faka and FU4S_S respectively; figs. 1 and 2). Rainfall from three SFWMD stations were also used in this analysis, the Southern Golden Gate Estates weather station, Dan House Prairie station, and Fakahatchee Strand North station (SGGEWX, DANHP, and FKSTRN; fig. 1). Flow, water temperature, specific conductance, and salinity data collected by the USGS are available for download from the National Water Information System (NWIS) database (U.S. Geological Survey, 2021). Rainfall and flow data from the SFWMD stations are available for download from the DBHYDRO database (South Florida Water Management District, 2020). This report describes the annual and monthly variability of streamflow and salinity across these stations and includes a trend analysis of rainfall-adjusted streamflow and rainfall-adjusted salinity.

\section{Description of Study Area}

The TTI estuary is a shallow, subtropical estuarine system that consists of numerous bays separated from the Gulf of Mexico by many small mangrove islands and tidal passes. The TTI geomorphology can be attributed to oyster and vermetiform gastropod reefs that provided substrate for mangrove settlement (Volety and others, 2009). Ten major rivers contribute freshwater to the northern TTI estuary (fig. 2). Flow to these rivers is controlled by topography and canal inputs (McCoy, 1972). Faka Union Canal flow is controlled by a fixed crest weir (fig. 3) with an elevation of 2 feet (ft) above the National Geodetic Vertical Datum of 1929 (South Florida Water Management District, 2013) and accounts for the majority of flow to the estuary. Local hydrology is affected by semidiurnal mixed tides with a range of approximately $3 \mathrm{ft}$.

Positive and negative flows occur at all stations. Positive flow indicates flow to the Gulf of Mexico, and negative flow indicates reverse flow. For the purpose of this report, Faka Union River refers to the USGS flow station that measures flow downstream from the confluence of the Faka Union Canal and the Faka Union River. Flow at Faka Union River can be negative even when the flows are positive at nearby

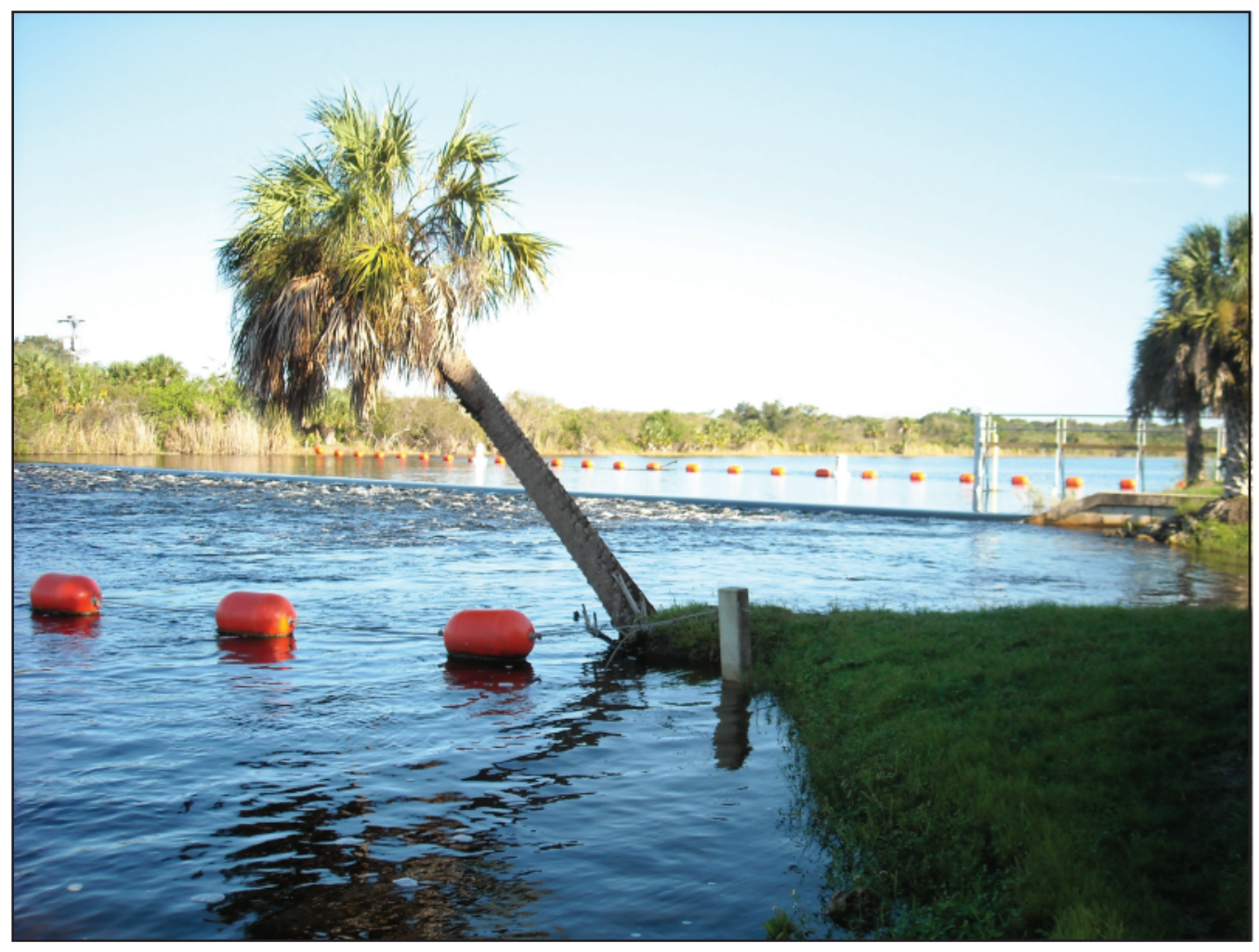

Figure 3. Faka Union weir, September 2009. 
rivers, potentially because of flow controlled by the weir. Negative cumulative flows are likely caused by water moving in with the flooding tide and not flowing out toward the Gulf with the ebbing tide. During high tide, the water can breach the tributary banks and flood the tidal wetlands; when the tide recedes, some of the water remains in the tidal wetlands.

The sea level rise trend is estimated at 0.122 inches per year (in/yr) with a confidence interval of plus or minus $0.017 \mathrm{in} / \mathrm{yr}$, from 1965 to 2020 for Naples, Florida (National Oceanic and Atmospheric Administration, 2021), which is located approximately $14 \mathrm{mi}$ northwest of Marco Island. This is similar, within $0.039 \mathrm{in} / \mathrm{yr}$, to trends observed along the west coast of Florida (National Oceanic and Atmospheric Administration, 2021).

The climate is subtropical with an average annual rainfall of 54 inches (in.) (Chuirazzi and others, 2015). The majority of the rainfall occurs during June through October. Summer rainfall events are typically short, intense, and frequent. Winter rainfall events are typically associated with weather fronts and are longer, less intense, and not as frequent as summer rainfall events (McCoy, 1972).

\section{Methods of Investigation}

Stage, flow, specific conductance, and temperature data were collected at USGS sites and supplemented by flow and rainfall data collected at SFWMD sites. Monthly mean flow and salinity values were computed from the data or estimated if insufficient data were available. Flow and salinity data were statistically analyzed for trends and for abrupt changes if trends were found to be statistically significant.

\section{Data Collection}

Continuous measurements of stage and flow were measured at several USGS river stations within the TTI estuary as part of this study (table 1; figs. 2 and 4). Stage data were collected using shaft encoders or pressure sensors. Acoustic Doppler velocity meters collected index velocity measurements. Manual measurements of flow were made over a wide range of conditions by hydrologic technicians approximately 6 days per year using acoustic Doppler current profilers. The index velocity method, which uses the relation between the mean channel velocity (as measured by the acoustic Doppler current profiler) and the index velocity (as measured by the acoustic Doppler velocity meter), was used to compute flow, using standard USGS methods (Levesque and Oberg, 2012). Data were tidally influenced at all monitoring stations, and therefore, flow data were filtered with the Godin low-pass filter to remove tidal frequencies according to USGS policy (Godin, 1972;

U.S. Geological Survey, 2010).

Data were summarized to mean daily values and stored in the NWIS database (U.S. Geological Survey, 2021). Additional flow data were obtained from the SFWMD
DBHYDRO database interface for Faka Union Canal at the weir, and Faka Union Canal weir 4 spillway (South Florida Water Management District, 2020) to provide additional insights on flow into the study area. The Faka station is referred to as the Faka Union Canal throughout the report.

The Faka Union Boundary station was initially located on channel marker 6. During Hurricane Irma in 2017, the station was destroyed and rebuilt near Panther Key in November of 2017, which is slightly upstream from the original location (fig. 2). For the purpose of this report, data from the two locations are combined and referred to as the Faka Union Boundary. Because the station was moved near the end of the study period, a trend analysis was not completed for Faka Union Boundary, but these data were summarized to characterize monthly and annual variability.

Specific conductance and temperature were monitored at 15-minute intervals at all USGS stations (table 1) using a YSI 600R, YSI 600XL, or Satlantic Seabird. Instruments were quality assured using standard USGS guidelines outlined by Wagner and others (2006). Near-surface and nearbottom salinity monitors were initially installed at all stations, with the exception of the Faka Union Boundary, to describe stratification. Near-surface salinity monitors were installed in floating mounts and recorded data at approximately $1 \mathrm{ft}$ below the water surface. Near-surface salinity was discontinued at all stations in 2011 because of minimal stratification observed in the water column. Near-bottom salinity monitors were installed at depths ranging from 4 to $8 \mathrm{ft}$ below the water surface. Water-quality monitoring data were processed using standard USGS methods (Wagner and others, 2006) at all USGS stations.

Rainfall data were downloaded from the SFWMD DBHYDRO database (South Florida Water Management District, 2020) for three stations. Data from rainfall station DANHP, located within Fakahatchee Strand Preserve State Park (fig. 1), and rainfall station SGGEWX were used in this analysis. Rainfall data consist of measurements from a rain gage augmented with radar-based rainfall data. Prior to October 2007, rainfall data consist solely of data obtained from the rain gage, because data augmented with radar-based data were not available. Missing data for May and June 2007 at DANHP were estimated to be zero based on data from a rainfall station about $13 \mathrm{mi}$ north-northeast of DANHP - the Fakahatchee Strand North rainfall station (FKSTRN, fig. 1).

\section{Data Analysis}

Monthly mean flow and salinity values were calculated with Aquarius software using instantaneous values if no more than 10 percent of the data for that month were missing. If more than 10 percent of the data were missing, the monthly data were estimated by first estimating the missing daily values using linear interpolation of observed data and then averaging these observed and estimated daily values for each month. Monthly mean flow data were converted to acre-feet 


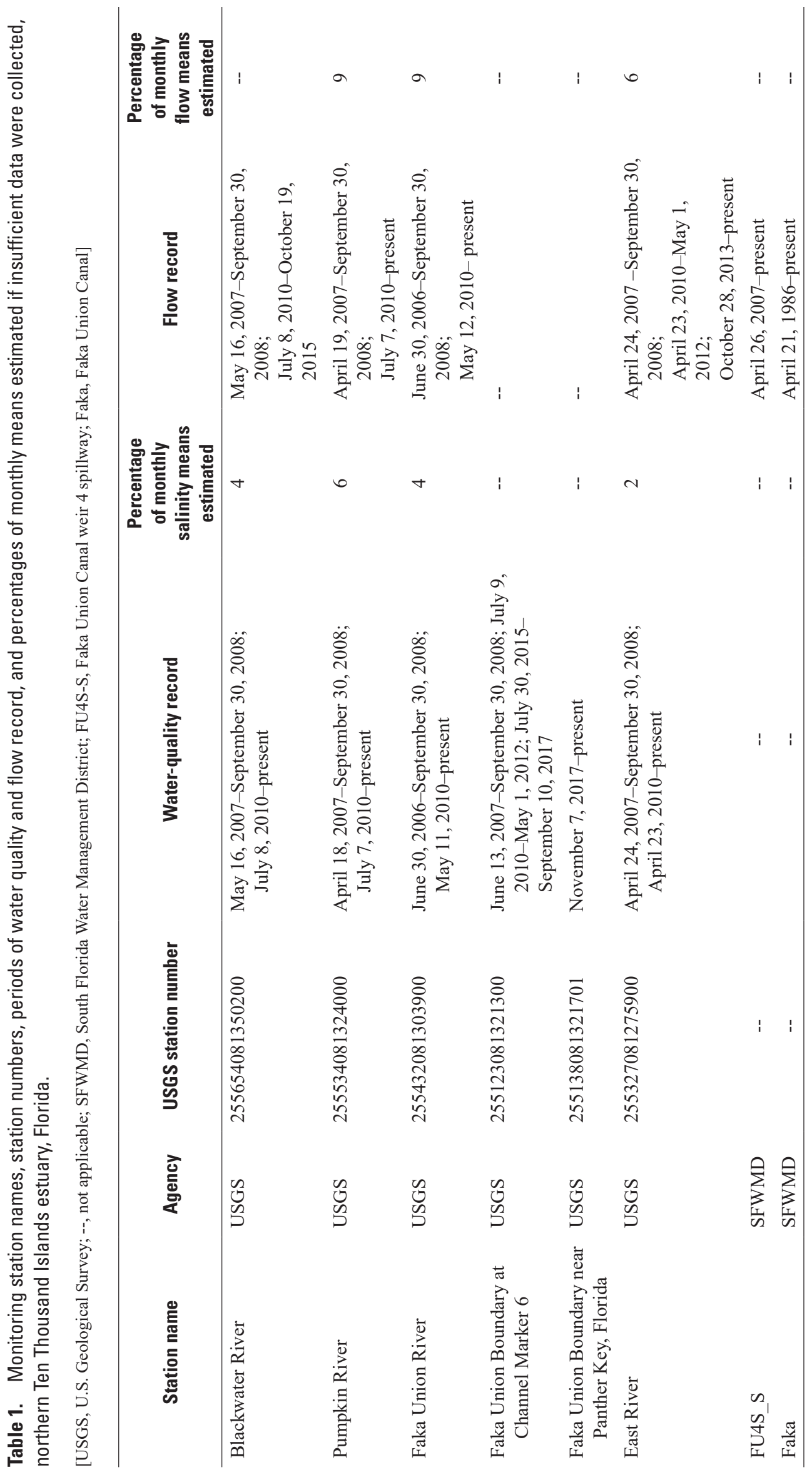




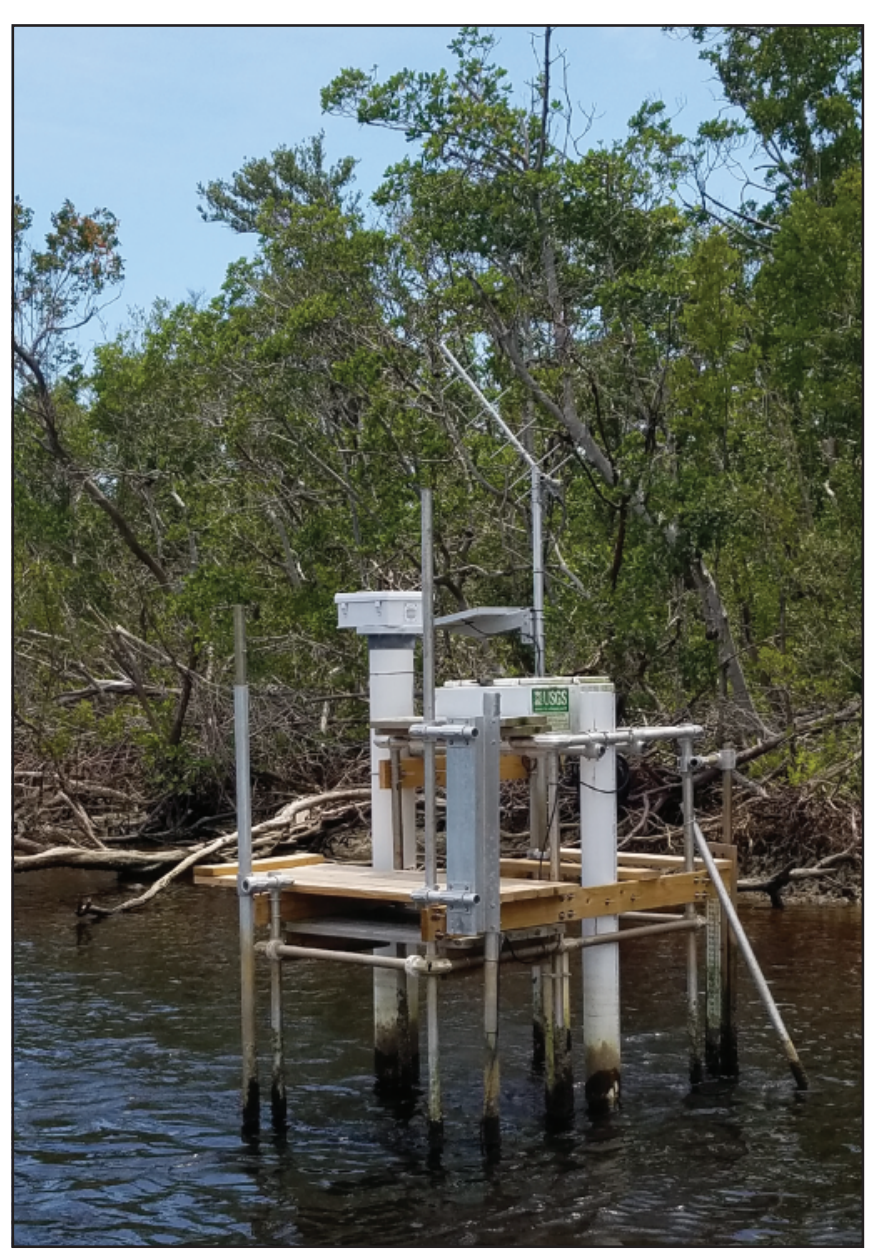

Figure 4. U.S. Geological Survey streamflow and water-quality station at Faka Union River, June 2018.

and multiplied by the number of days in the month to compute the cumulative volume of flow over each month; the sum of monthly volumes was then used to calculate annual flow. Annual and monthly flows, as well as monthly mean salinity values, differ slightly from the calculations presented in Booth and others (2014) because of rounding differences between Excel software used previously and the Aquarius software used in this current analysis. The relative percent differences in annual flow between this report and the previous report range from -0.68 percent (absolute difference 10 acre-feet) to 3.03 percent (absolute difference of 6 acre-feet).

Statistical analysis was conducted using R (R Core Team, 2020), and the EnvStats R package (Millard, 2013) was used for the Seasonal-Kendall tests. The Seasonal-Kendall test is a nonparametric test used to detect monotonic trends, and it runs a Mann-Kendall trend test on each of the seasons defined (Helsel and others, 2020). The Seasonal-Kendall test within the EnvStats package indicates the direction of the trend based on the Kendall tau, the rate of change using the Theil-Sen slope estimate, and a comparison of seasonal slopes using the chi-square heterogeneity test. The analysis defined seasons as months to account for seasonal changes in rainfall. The Seasonal-Kendall test can be run on datasets with nonnormal distributions and is not sensitive to outliers. The test assumes no serial correlation is present in the data. Each dataset was tested for serial correlation using the rank version of the von Neumann test for autocorrelation within the EnvStats package.

Exogenous variables represent natural phenomena that, in addition to time, can influence the response of time series data. Accounting for the explanatory value of exogenous variables on the response variable reduces the background variation of time series data and increases the ability of the trend test to discern meaningful temporal changes. Monthly rainfall totals were used as the exogenous variable for the analysis of both salinity and flow to reduce the influence of variations in rainfall on flow and salinity trends. A locally weighted smoothing (LOESS) curve of the response variable (flow or salinity) versus the exogenous variable (rainfall) was used to generate rainfall-adjusted flow and rainfall-adjusted salinity. The Seasonal-Kendall test was performed on the residuals of the LOESS curves for all available data from July 2006 to September 2008 and May 2010 to September 2019. DANHP data were used for rainfall for all analyses with the exception of flow at FU4S_S, where rainfall data from SGGEWX were used. Trends in rainfall (July 2006 to September 2019) were also evaluated using the Seasonal-Kendall test without accounting for an exogenous variable.

Pettitt's test for change-point detection (Pettitt, 1979) was used to test for abrupt changes in the time series data for a given location if the Seasonal-Kendall test found a significant trend. The Pettitt test was run on salinity and flow data from July 2006 to September 2008 and May 2010 to September 2019 using the R package Trend (Pohlert, 2020). The result of the Pettitt test gives the first significant change in the time series being tested. The significance level was defined as $\alpha=0.05$ for all tests.

\section{Annual and Monthly Variability and Trends in Rainfall}

The average annual rainfall at DANHP for 2007-19 was $54.1 \mathrm{in}$. and at SGGEWX for 2008-19 was $63.1 \mathrm{in}$. (South Florida Water Management District, 2020). The highest yearly rainfall occurred in water year 2017 (85.8 in. at DANHP and 89.0 in. at SGGEWX), and the lowest yearly rainfall was in 2011 (39.9 in. at DANHP and 47.4 in. at SGGEWX) (fig. 5). The monthly mean rainfall, across all months, for the study period was $4.5 \mathrm{in}$. at DANHP and $5.3 \mathrm{in}$. at SGGEWX. Monthly mean rainfall averaged less than 2 in. during November-April at both stations. Typically, the highest rainfall amounts were observed during June-September. At DANHP the highest monthly rainfall total during the study period was 22.6 in. for June 2017, followed by $21.2 \mathrm{in}$. for September 2017. At SGGEWX the highest monthly rainfall 


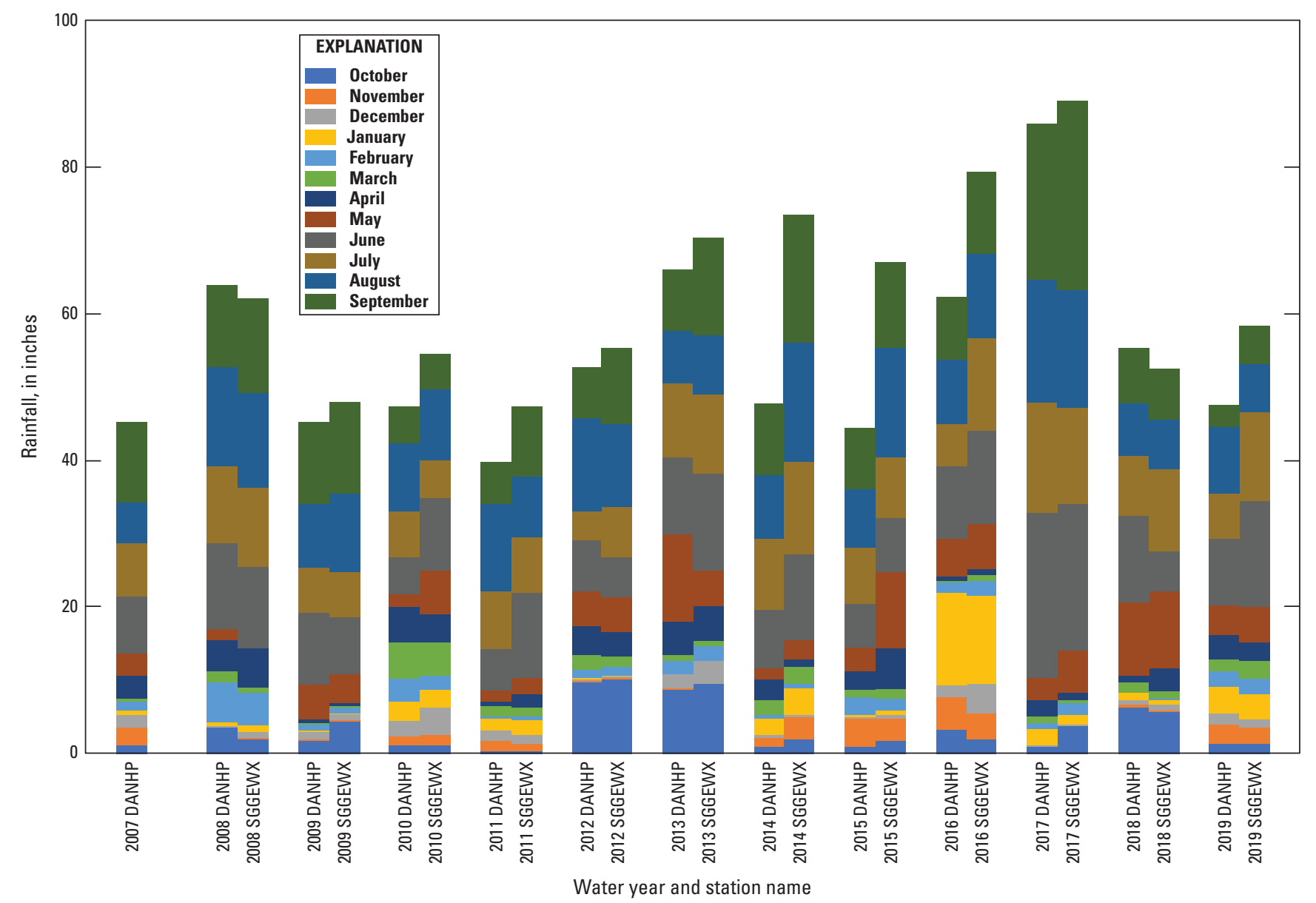

Figure 5. Monthly and annual rainfall in the northern Ten Thousand Islands estuary, water years 2007-19, calculated using data obtained from the South Florida Water Management District rainfall stations, Dan House Prairie (DANHP) and Southern Golden Gate Estates (SGGEWX).

total during the study period was 25.8 in. for September 2017, followed by 20.1 in. for June 2017. September 2017 rainfall data were influenced by Hurricane Irma. June 2017 rainfall data were influenced by an area of low pressure in the Gulf of Mexico (National Oceanic and Atmospheric Administration and National Weather Service, 2017). The 2016 water year was unique in that 12.6 in. of rain were measured at DANHP and $12.1 \mathrm{in}$. of rain were measured at SGGEWX in January. Excluding 2016, the average rainfall in January for the study period was 1.3 and 1.4 in., respectively, at these sites. The Seasonal-Kendall test indicated that there was no trend in monthly rainfall totals at DANHP from July 2006 to September 2019 and at SGGEWX from October 2007 to September 2019 (table 2). There was also no significant difference in the trends between the months at either rain gage, based on the chi-square p-values (table 2).

Two named tropical systems affected the area during the study period after making their initial landfall in the Florida Keys. Tropical Storm Fay made landfall at Cape Romano, Florida, shortly before 5 a.m. on August 19, 2008, with maximum sustained winds of 60 miles per hour (National Oceanic and Atmospheric Administration, 2008). DANHP

Table 2. Seasonal-Kendall trend analysis for rainfall by station.

[DANHP, Dan House Prairie rainfall station; SGGEWX, Southern Golden Gate Estates weather station]

\begin{tabular}{llccc}
\hline \multicolumn{1}{c}{ Station } & \multicolumn{1}{c}{ Trend } & $\begin{array}{c}\text { Trend } \\
\text { p-value }\end{array}$ & Tau & $\begin{array}{c}\text { Seasonal p-value } \\
\text { (chi) }\end{array}$ \\
\hline DANHP & No trend & 0.732 & 0.024 & 0.778 \\
SGGEWX & No trend & 0.096 & 0.107 & 0.531 \\
\hline
\end{tabular}


recorded 2.8 in. of rain on August 18 and 2.9 in. of rain on August 19 (South Florida Water Management District, 2020). Hurricane Irma made landfall near Marco Island, Fla., as a category 3 with winds of 115 miles per hour (Cangialosi and others, 2017). DANHP recorded 1.5 in. of rain on September 9, 2017, and 12.6 in. of rain on September 10 (South Florida Water Management District, 2020). Rainfall from both storms substantially affected the area by increasing flows and decreasing salinities.

\section{Flow Characteristics and Salinity Patterns in the Ten Thousand Islands}

Faka Union River was found to be the largest contributor of freshwater to the TTI estuary, followed by East River and Pumpkin River. This observation was to be expected because the restoration is not complete, and most of the Picayune Strand State Forest and Northern Golden Gate Estates drains into the Faka Union Canal. East River receives the majority of its flow from the Fakahatchee Strand, which is less anthropogenically influenced compared to the Picayune Strand (fig. 1). Most sites showed positive trends in rainfall-adjusted monthly flow, and all sites showed negative trends in rainfall-adjusted monthly salinity. Salinities varied widely, were affected by freshwater inputs, and generally were higher at stations in the western part of the study area than in the eastern part.

\section{Annual and Monthly Flow Characteristics of Tidal Rivers}

Annual and monthly flow characteristics were calculated for three tidal rivers, Faka Union River, Pumpkin River, and East River. Annual flow was highest at Faka Union River and Pumpkin River in 2017 and at East River in 2016 (fig. 6). Annual flow was lowest in 2011 at Pumpkin and East Rivers (no data were recorded in 2012 and 2013 at East River) and lowest in 2015 at Faka Union River.

Comparison of flow at East River, Faka Union River, and Pumpkin River showed that Faka Union River accounted for 83-95 percent of the monitored flow, depending on the year, over the study period (fig. 7). During the years with the lowest rainfall (2008 and 2011), flow contribution percentages for East River were lowest and those for Faka Union were highest. Pumpkin River contributions varied minimally throughout the study period, ranging from 0 to 2 percent.

Monthly flows at the three tidal river stations vary over the course of a year (figs. 8 and 9A). On average, flows peak in September at all three stations. East River and Faka Union River have similar seasonal patterns, with the lowest flows occurring in April and May. The seasonal pattern of flows at Pumpkin River is less consistent, and some of the lowest flows observed occurred during June and October. Similar to the Faka Union River and East River, the highest monthly flows at
Pumpkin River were observed during August and September. The high monthly flows in August and September 2017 can be attributed to the large amount of rainfall between June and August (54.4 in. for 3 months). An additional 21.2 in. fell in the month of September and can be partially attributed to Hurricane Irma in 2017. Increases in monthly flows corresponded with increases in monthly rainfall (fig. 9).

The percentage of monthly flows that were negative varied widely between years and stations, ranging from 0 to 58 percent (table 3 ). For a given site, variation among years was as high as 50 percent. For a given year, variation among sites was also as high as 50 percent. Total monthly flows were negative during 19, 29, and 31 percent of the study period for Faka Union, East, and Pumpkin Rivers, respectively.

\section{Trends in Flow}

Positive trends in rainfall-adjusted flow were found at four of the stations, and no trend was observed at Pumpkin River (table 4). The monthly slopes for each river were not significantly different at any of the monitoring stations, based on the chi-square heterogeneity test $\mathrm{p}$-value. The trend analysis slope of 15.02 cubic feet per second per year $\left(\left[\mathrm{ft}^{3} / \mathrm{s}\right] / \mathrm{yr}\right)$ for the USGS Faka Union River station is slightly higher than the 14.19-( $\left.\mathrm{ft}^{3} / \mathrm{s}\right) / \mathrm{yr}$ slope for the Faka Union Canal SFWMD station, indicating that in addition to the canal inputs, the Faka Union River contributes to the total flow registered at the USGS Faka Union River station. The confidence intervals for the trend analysis slope at Faka Union Canal and Faka Union River overlap, indicating that the slope for both stations may be equivalent. The increase in flow at East River was $2.73\left(\mathrm{ft}^{3} / \mathrm{s}\right) / \mathrm{yr}$. Increases in flow at Faka Union and East Rivers may be due to an increase in flow into the study area from canals upstream. FU4S_S is located on the Faka Union Canal north of I-75 and provides insight about water entering the study area. The flow trend was positive for FU4S_S, indicating that increased flows downstream could be attributed to an increase in canal flows upstream. The trend slope at FU4S_S was not calculated because of the number of zero-flow periods at the station. Increased flows to the study area from canals upstream are likely distributed through the Faka Union Canal or to the east of it. No increased flow was expected at Pumpkin River, because any increase would be funneled toward the Faka Union Canal.

The results from the Pettitt test show a significant change in flow at Faka Union River and Faka Union Canal in August 2015, coinciding with the initial operations of the upstream pump, S-488, as well as the plugging of Merritt Canal. The Pettitt test is not presented for East River because of the large period when data were not collected in 2012 and 2013. While the Pettitt test was not run at FU4S_S because of the large periods of zero flow, the mean flow for FU4S_S from April 2007 through July 2015 was $5.1 \mathrm{ft}^{3} / \mathrm{s}$, compared to a mean of $18.1 \mathrm{ft}^{3} / \mathrm{s}$ for August 2015 to September 2019. 

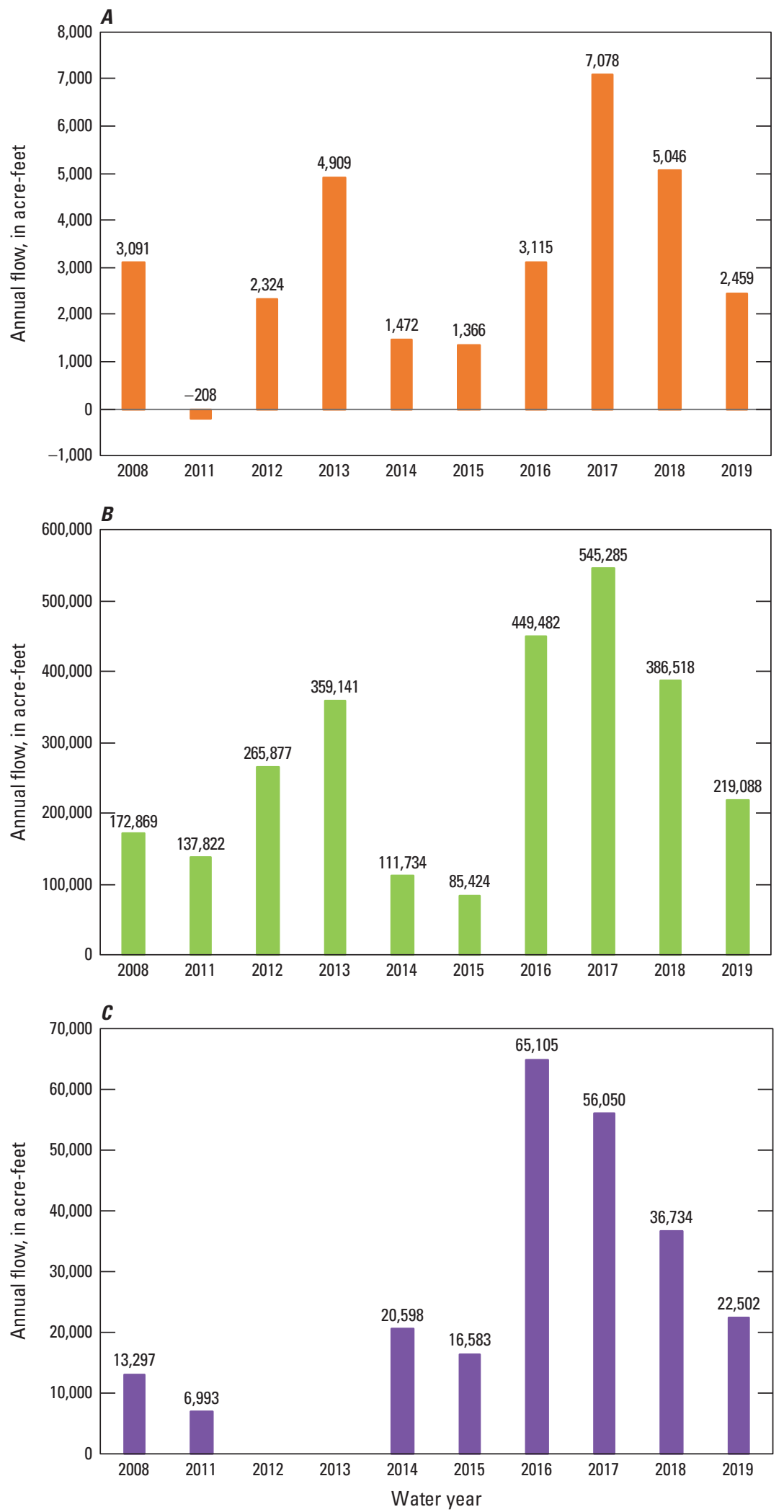

Figure 6. Annual flow at tidal tributaries, water years 2008 and 2011-19: A, Pumpkin River, $B$, Faka Union River, and $C$, East River. No data were collected in 2012 and 2013 at East River. 


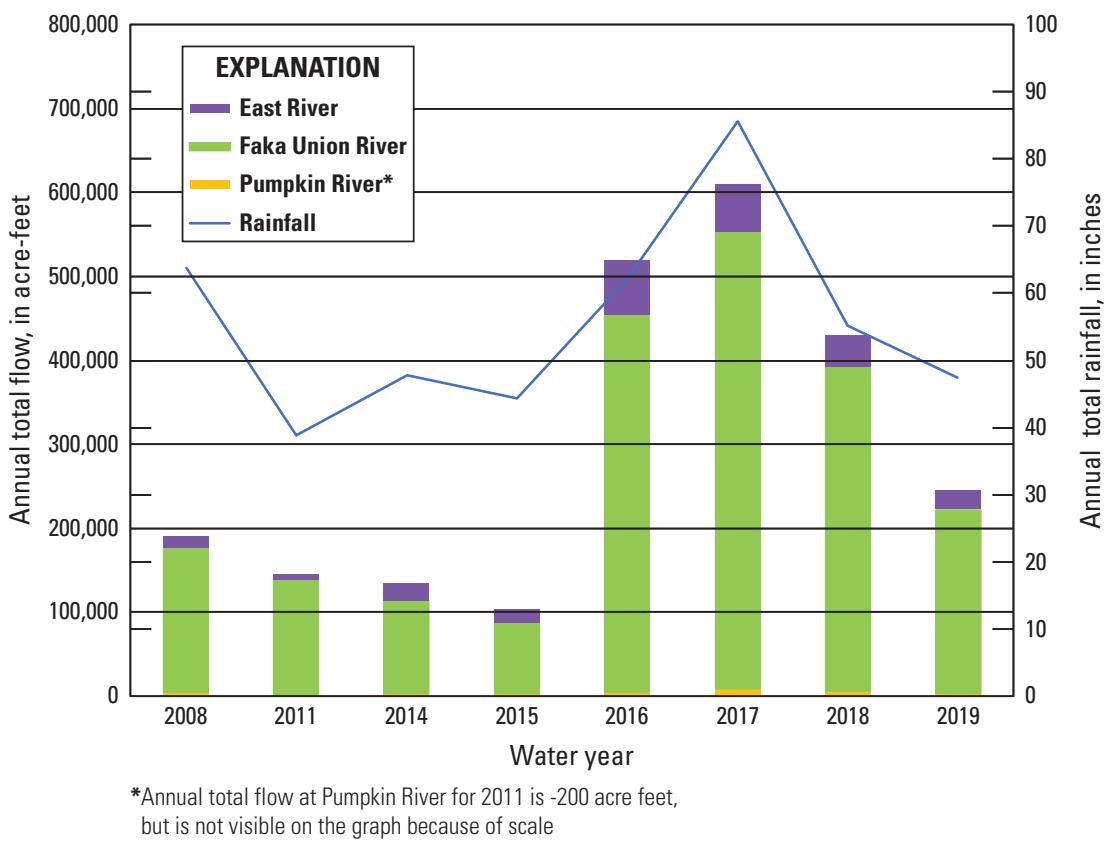

Figure 7. Flow contributed by Pumpkin River, Faka Union River, and East River, water years 2008, 2011, and 2014-19 and annual rainfall totals at Dan House Prairie (DANHP).

\section{Salinity Patterns and Trends in Tidal Rivers and Bays}

Annual and instantaneous salinities varied widely between sites and years, and these patterns were typically related to proximity in time and space to freshwater inputs. Salinity tended to be highest at Faka Union Boundary compared to the other stations because of its proximity to the Gulf of Mexico. At all stations, annual mean salinities were highest in 2011, corresponding with the lowest annual rainfall total during the study period (figs. 5 and 10). Annual mean salinities were lowest in 2016 at all stations, coinciding with the fourth highest annual mean rainfall across the study period. Monthly rainfall in 2016 did not follow the typical seasonal pattern, with 12.6 in. of rain occurring in January, over five times the monthly average for January during the study. The maximum and minimum instantaneous salinities did not occur during the same years as the maximum and minimum annual mean salinities. Instantaneous salinity varied widely throughout the years during this study (fig. 10). With the exception of East River, all of the instantaneous maximum salinity values occurred in 2008 and ranged from 41.2 to 43.4 ppt. The instantaneous maximum for East River was also 41.2 ppt but occurred in 2013. The lowest instantaneous salinity values at each station occurred in 2017 and ranged from 0.2 to 1.6 ppt.

The monitoring sites west of the Faka Union canal had the greatest percentages of salinities equal to or greater than $35 \mathrm{ppt}$, which indicates a seawater environment. When salinities are consistently at $35 \mathrm{ppt}$, the area does not function as an estuarine environment, which is an environment critical in the life stages of many marine organisms. The highest percentage of instantaneous salinities greater than or equal to $35 \mathrm{ppt}$ occurred in 2008 at Faka Union Boundary, 2011 at East River and Pumpkin River, and 2017 at Blackwater River and Faka Union River (table 5). The lowest percentage of salinities equal to or greater than 35 ppt occurred in 2016 at Pumpkin River and Blackwater River ( 0.2 and 2.3 percent of the year, respectively). Instantaneous salinities were less than $35 \mathrm{ppt}$ during all of 2016 at East River, Faka Union River, and Faka Union Boundary (table 5). Although 2016 did not correspond with the highest rainfall totals, it was an above average year for rainfall with 12.6 in. recorded in January.

The timing of monthly minimum and maximum salinities was similar across stations, with strong seasonal patterns related to rainfall and streamflow. The lowest monthly mean salinities occurred at Faka Union River and East River (fig. 11, table 6) indicating they received a greater amount of freshwater than the other sites. The minimum monthly mean at both sites occurred in September 2017. The Faka Union Boundary does not have data for September 2017, because the station was destroyed by Hurricane Irma. Monthly mean salinity at Faka Union Boundary was lowest during the previous month, August 2017. The maximum monthly salinity occurred in May 2008 for all stations except East River (May 2011).

Rainfall-adjusted monthly means for salinity had negative trends for all stations during the study period. The slopes were not statistically different between months, based on the chi-square heterogeneity test at any of the monitoring 

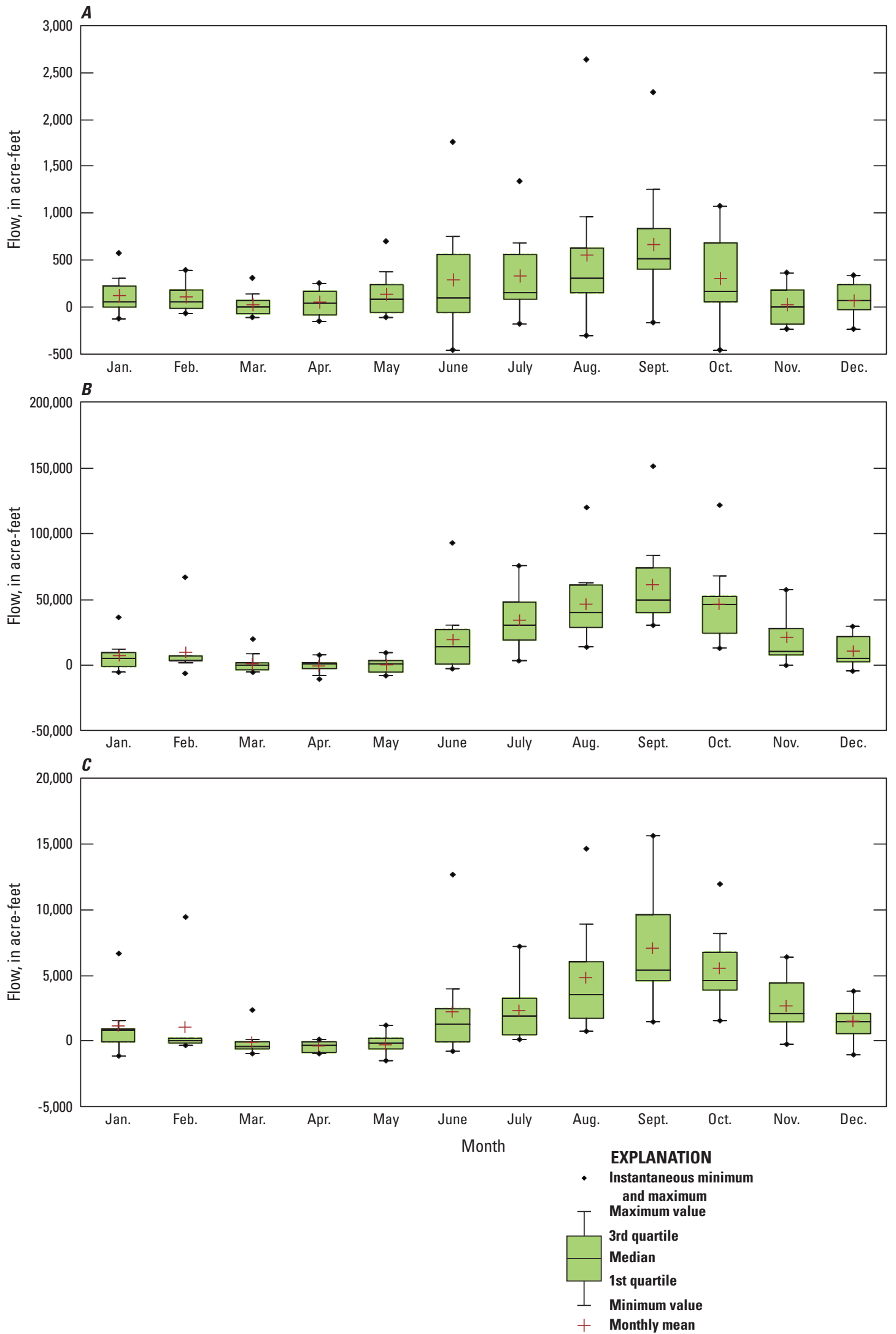

Figure 8. Monthly flow data by station. $A$, Pumpkin River, $B$, Faka Union River, and $C$, East River. 

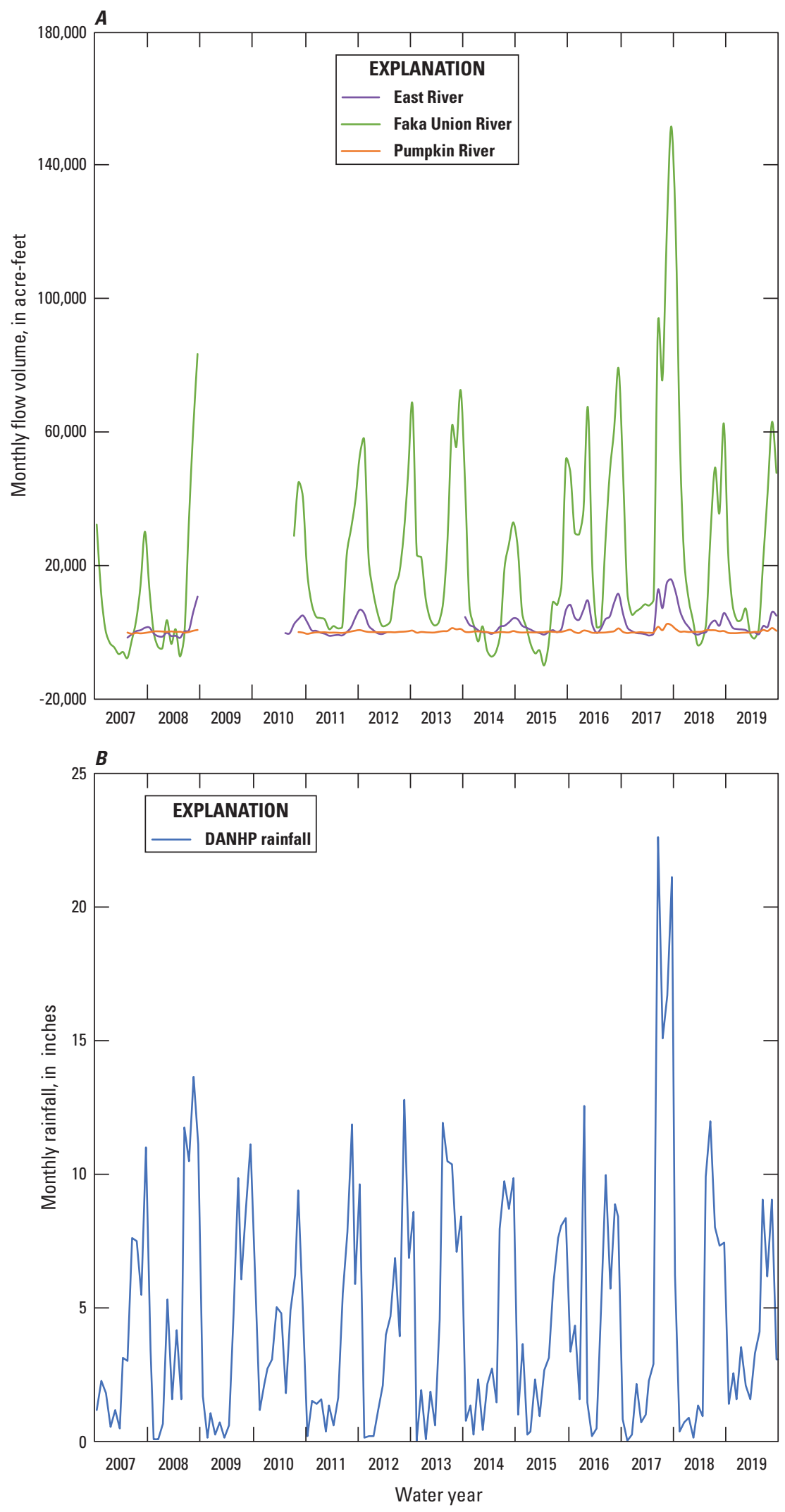

Figure 9. A, Monthly rainfall at Dan House Prairie (DANHP) and flow at Pumpkin River, East River, and Faka Union River, water years 2007-19. B, Monthly rainfall at DANHP and flow at East River and Pumpkin River. 
Table 3. Percentage of total monthly flow that was negative during water years 2008 and 2011-19 in the northern Ten Thousand Islands estuary.

$[--$, no data collected during this period]

\begin{tabular}{cccc}
\hline Water year & $\begin{array}{c}\text { Pumpkin River } \\
\text { (percent) }\end{array}$ & $\begin{array}{c}\text { Faka Union } \\
\text { River (per- } \\
\text { cent) }\end{array}$ & $\begin{array}{c}\text { East River } \\
\text { (percent) }\end{array}$ \\
\hline 2008 & 8 & 50 & 58 \\
2011 & 50 & 0 & 50 \\
2012 & 0 & 0 & -- \\
2013 & 25 & 0 & -- \\
2014 & 25 & 42 & 8 \\
2015 & 25 & 42 & 17 \\
2016 & 42 & 0 & 8 \\
2017 & 50 & 0 & 42 \\
2018 & 0 & 25 & 25 \\
2019 & 50 & 17 & 17 \\
\hline
\end{tabular}

Table 4. Trend analysis of rainfall-adjusted flow by station.

[FU4S_S, Faka Union Canal weir 4 spillway]

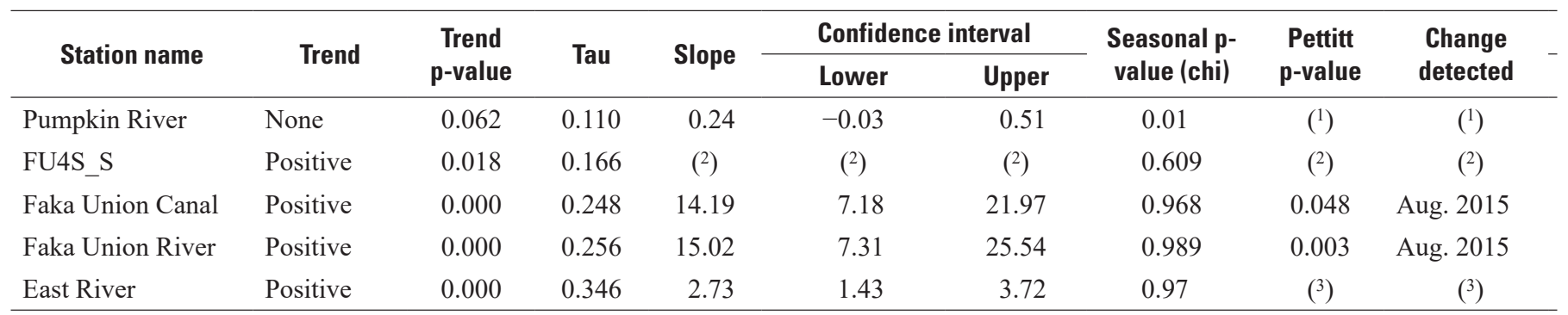

${ }^{1}$ The Pettitt test was not run for Pumpkin River data because no change was detected.

${ }^{2}$ The slope and Pettitt test were not run for FU4S_S data because of the large periods of zero flow.

${ }^{3}$ The Pettitt test was not run for East River data because of the extended period when data were not collected in 2012 and 2013.

stations. The slope of the rainfall-adjusted trend ranged from -0.331 ppt per year at Blackwater River to -0.515 ppt per year at East River (table 7). The overlapping confidence intervals for the annual slope indicate the overall magnitude of change is similar among stations. Slopes were slightly more negative at East River and Faka Union River than other sites and had increasing trends in streamflow over this time.

The Pettitt test indicates that the trends at East River and Pumpkin River were due to an abrupt change in August 2015 (table 7). The August 2015 change period corresponds with the initial operations of the Merritt Pump Station as well as the plugging of Merritt Canal. The trend at Pumpkin River is proposed to be associated with increases in flow at Faka Union River, East River, and (or) unmonitored tributaries in addition to tidal mixing in the area, as the trend analysis showed no increase in flows at Pumpkin River. The May 2013 change timeframe at Faka Union River ( $p$-value $=0.045$ ) does not have a clear association with activities related to restoration efforts. 

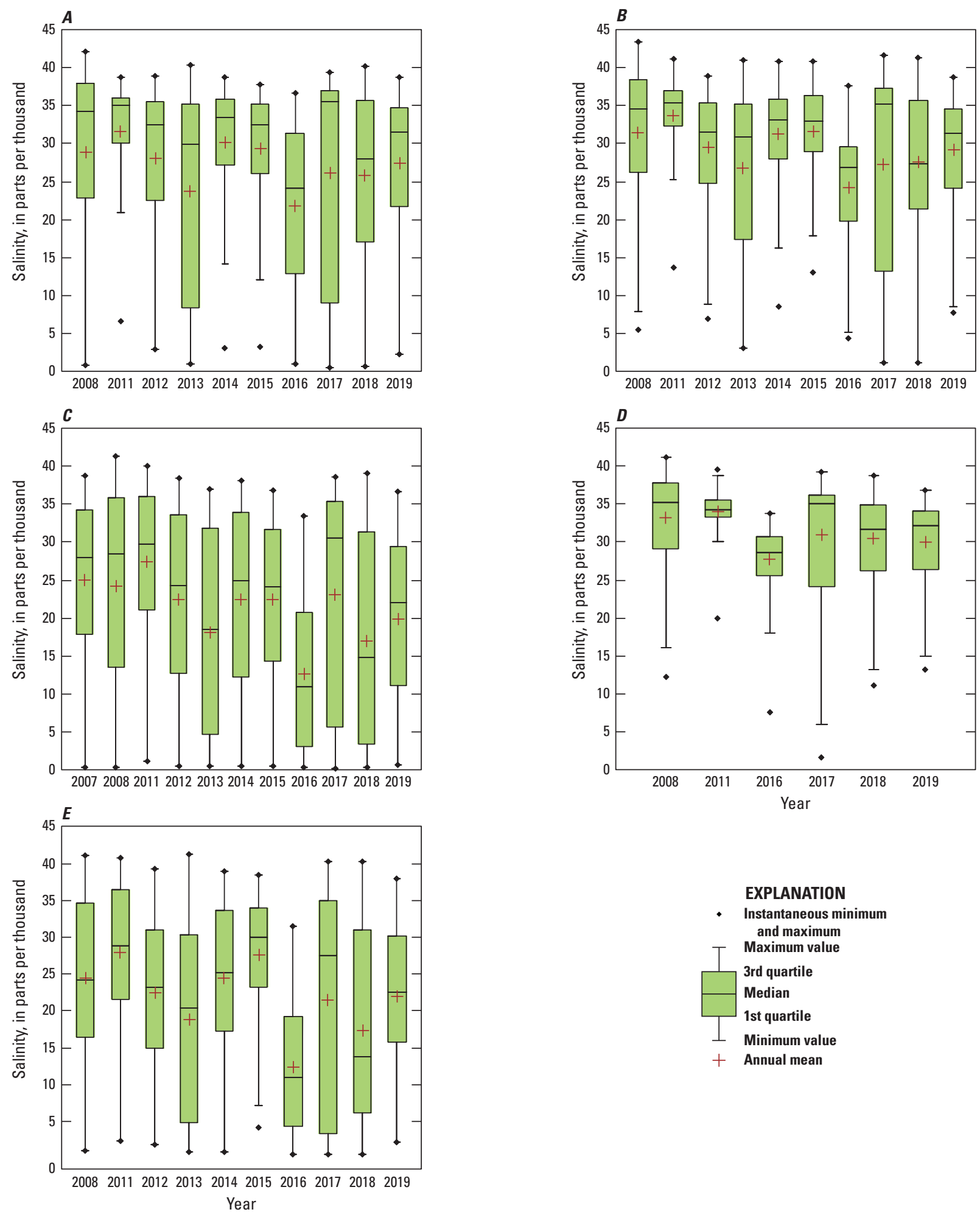

Figure 10. Salinity data by station and water year. $A$, Blackwater River, $B$, Pumpkin River, $C$, Faka Union River, D, Faka Union Boundary, and E, Blackwater River. The data for 2018 and 2019 at Faka Union Boundary are from Faka Union Boundary at Panther Key. 
Table 5. Percentage of instantaneous salinity values greater than or equal to 35.0 parts per thousand, water years 2007-08 and 2011-19, in the northern Ten Thousand Islands estuary.

$[--$, no data collected during this period]

\begin{tabular}{cccccc}
\hline Water year & $\begin{array}{c}\text { Blackwater } \\
\text { River }\end{array}$ & Pumpkin River & $\begin{array}{c}\text { Faka Union } \\
\text { River }\end{array}$ & $\begin{array}{c}\text { Faka Union } \\
\text { Boundary }\end{array}$ & East River \\
\hline 2007 & -- & -- & 18.4 & -- & -- \\
2008 & 47.4 & 48.3 & 29.6 & 51.1 & 23.7 \\
2011 & 50.7 & 57.0 & 28.4 & 30.7 & 29.0 \\
2012 & 34.6 & 29.3 & 19.7 & -- & 8.1 \\
2013 & 28.4 & 25.7 & 11.1 & -- & 7.8 \\
2014 & 39.5 & 34.9 & 20.3 & -- & 16.4 \\
2015 & 37.1 & 30.7 & 9.1 & -- & 17.8 \\
2016 & 2.3 & 0.2 & 0.0 & 0.0 & 0.0 \\
2017 & 53.8 & 38.2 & 29.9 & 32.1 & 24.8 \\
2018 & 29.8 & 32.0 & 13.0 & 24.7 & 14.7 \\
2019 & 22.8 & 19.0 & 2.1 & 6.5 & 7.1 \\
\hline
\end{tabular}

${ }^{1}$ The data for 2018 and 2019 at Faka Union Boundary are from Faka Union Boundary at Panther Key.

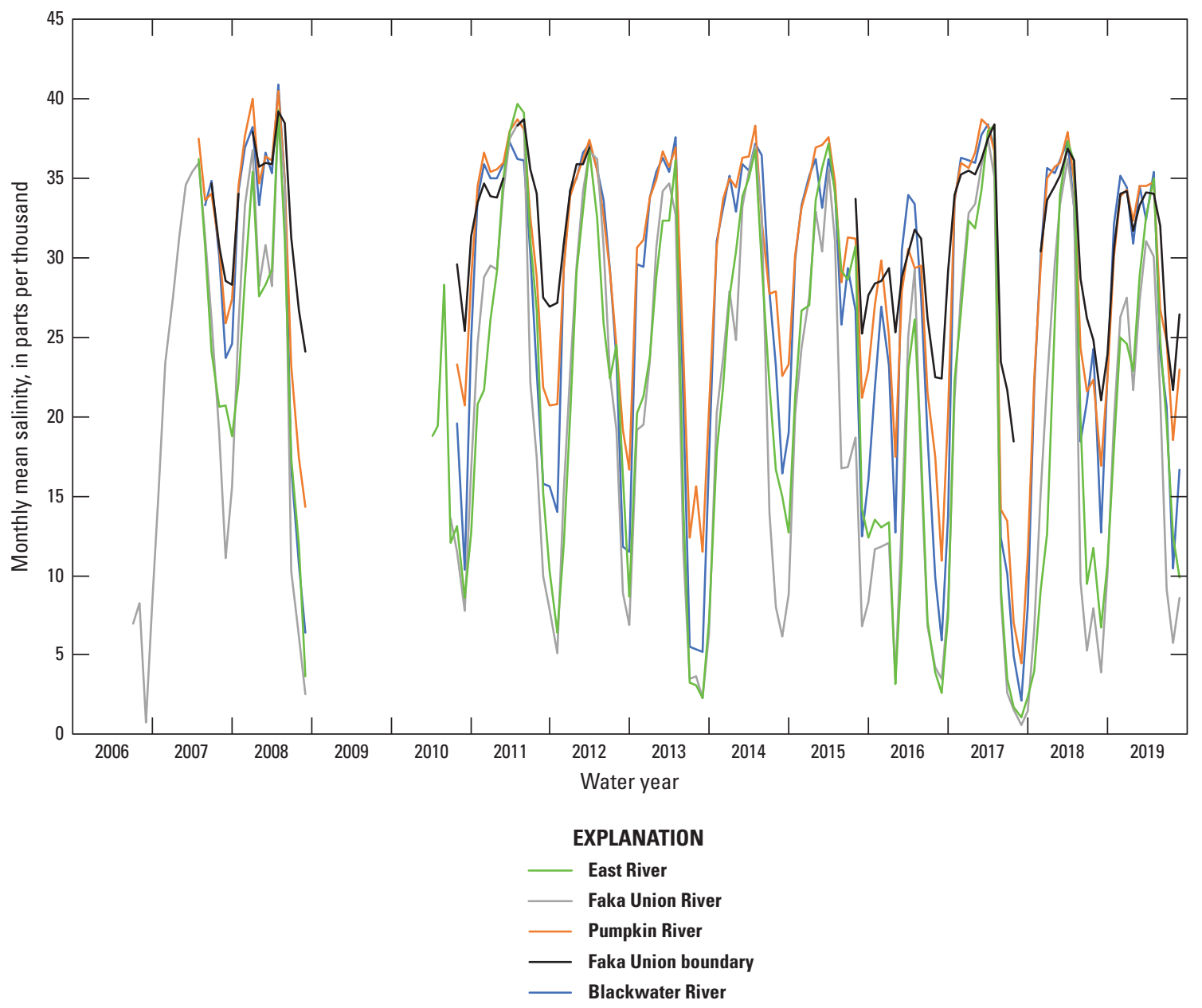

Figure 11. Monthly mean salinity values by station, July 2006-September 2019, Ten Thousand Islands estuary area. The data for 2018 and 2019 at Faka Union Boundary are from Faka Union Boundary at Panther Key. 
Table 6. Maximum and minimum monthly salinity means, water years 2007-08 and 2011-19, in the northern Ten Thousand Islands estuary.

[--, no data collected during this period]

\begin{tabular}{|c|c|c|c|c|c|}
\hline $\begin{array}{l}\text { Water } \\
\text { year }\end{array}$ & Blackwater River & Pumpkin River & $\begin{array}{c}\text { Faka Union } \\
\text { River }\end{array}$ & $\begin{array}{c}\text { Faka Union } \\
\text { Boundary }\end{array}$ & East River \\
\hline \multicolumn{6}{|c|}{ Maximum monthly mean } \\
\hline 2007 & -- & -- & 36.0 & -- & -- \\
\hline 2008 & 40.9 & 40.5 & 39.0 & 39.2 & 39.3 \\
\hline 2011 & 37.3 & 38.7 & 38.7 & 38.7 & 39.7 \\
\hline 2012 & 37.2 & 37.4 & 36.7 & -- & 36.8 \\
\hline 2013 & 37.5 & 36.9 & 34.7 & -- & 36.1 \\
\hline 2014 & 37.2 & 38.3 & 37.0 & -- & 36.8 \\
\hline 2015 & 36.2 & 37.6 & 35.6 & -- & 37.1 \\
\hline 2016 & 33.9 & 30.6 & 29.3 & 31.8 & 26.1 \\
\hline 2017 & 38.4 & 38.7 & 37.5 & 38.4 & 38.3 \\
\hline 2018 & 37.3 & 37.9 & 36.2 & 36.9 & 37.3 \\
\hline 2019 & 35.4 & 34.8 & 31.0 & 34.2 & 35.0 \\
\hline \multicolumn{6}{|c|}{ Minimum monthly mean } \\
\hline 2007 & -- & -- & 8.4 & -- & -- \\
\hline 2008 & 6.4 & 14.3 & 2.5 & 24.1 & 3.7 \\
\hline 2011 & 15.8 & 21.8 & 10.0 & 27.5 & 12.7 \\
\hline 2012 & 11.8 & 19.2 & 5.1 & -- & 6.4 \\
\hline 2013 & 5.2 & 11.5 & 2.3 & -- & 2.3 \\
\hline 2014 & 16.4 & 20.5 & 6.2 & -- & 7.1 \\
\hline 2015 & 12.5 & 21.2 & 6.8 & -- & 12.7 \\
\hline 2016 & 6.0 & 11.0 & 3.3 & 22.4 & 2.7 \\
\hline 2017 & 2.1 & 4.2 & 0.7 & 18.5 & 1.1 \\
\hline 2018 & 8.1 & 9.9 & 1.5 & 21.0 & 2.3 \\
\hline 2019 & 10.5 & 18.5 & 5.8 & 21.7 & 9.9 \\
\hline
\end{tabular}

Table 7. Trend analysis on rainfall-adjusted salinity by station.

\begin{tabular}{llccccccccc}
\hline \multicolumn{1}{c}{ Station name } & Trend & $\begin{array}{c}\text { Trend } \\
\text { p-value }\end{array}$ & Tau & Slope & $\begin{array}{c}\text { Lower } \\
\text { confidence } \\
\text { interval }\end{array}$ & $\begin{array}{c}\text { Upper } \\
\text { confidence } \\
\text { interval }\end{array}$ & $\begin{array}{c}\text { Seasonal p- } \\
\text { value (chi) }\end{array}$ & $\begin{array}{c}\text { Pettitt } \\
\text { p-value }\end{array}$ & $\begin{array}{c}\text { Change } \\
\text { detected }\end{array}$ \\
\hline Blackwater River & Negative & 0.001 & -0.231 & -0.331 & -0.604 & -0.179 & 0.876 & 0.103 & May 2013 \\
Pumpkin River & Negative & 0.000 & -0.291 & -0.385 & -0.601 & -0.208 & 0.976 & 0.028 & Aug. 2015 & May 2013 \\
Faka Union River & Negative & 0.000 & -0.232 & -0.452 & -0.690 & -0.234 & 0.988 & 0.045 & Aug. 2015 \\
East River & Negative & 0.010 & -0.180 & -0.515 & -0.874 & -0.217 & 0.932 & 0.024 & Aug \\
\hline
\end{tabular}




\section{Summary}

Freshwater flow to the Ten Thousand Islands (TTI) estuary has been altered by the construction of the Tamiami Trail (U.S. Highway 41) and the Southern Golden Gate Estates, a now defunct residential subdivision. The Picayune Strand Restoration Project, which is associated with the Comprehensive Everglades Restoration Plan, has been implemented to improve freshwater delivery to the TTI estuary by removing hundreds of miles of roads, emplacing hundreds of canal plugs, removing exotic vegetation, and constructing three pump stations. The U.S. Geological Survey, in cooperation with U.S. Army Corps of Engineers, initiated an ongoing study in 2006 with the purpose of monitoring flow and salinity patterns in the TTI estuary prior to, during, and after completion of restoration efforts. This report describes tributary flow and salinity patterns from 2007 to 2019 and characterizes streamflow and salinity conditions of the estuary during preliminary restoration efforts. These data serve as baseline data and document the influence of ongoing restoration efforts as part of the Picayune Strand Restoration Project.

Flow past the U.S. Geological Survey's Faka Union River station, which is downstream from the confluence of the Faka Union Canal and the Faka Union River, was the dominant contributor of freshwater to the TTI estuary, supplying more than 80 percent of the monitored annual flow during water years 2008-19. East River was the next largest contributor of annual flow (contributing 5-6 percent of monitored flow) and Pumpkin River contributed 1-2 percent of the monitored flow. This is expected because until the Picayune Strand Restoration Project is completed, the Faka Union Canal receives substantial drainage from multiple canals, which is not the case for Pumpkin and East Rivers. East River is downstream of the Fakahatchee Stand, which is a larger contributing area than the current contributing area for Pumpkin River. Variations in flow are seasonal and correspond with rainfall variations; flows typically begin to increase in June and peak in September. Total monthly flows were negative (in the inland direction) between 19 and 31 percent of the study period, depending on the river. The Seasonal-Kendall test indicated positive trends in rainfall-adjusted flow at Faka Union River and East River, and no significant trend at Pumpkin River. The positive trends are proposed to be due to an increase in flows into the study area from canals upstream. The results from the Pettitt test show a significant, abrupt increase in flow at the Faka Union River station and the South Florida Water Management District's Faka Union Canal station in August 2015, coinciding with the plugging of the Merritt Canal and initial operation of pump S-488.

Instantaneous, monthly, and annual salinity values varied widely from year to year but followed general trends among stations. The highest annual mean salinities occurred in water year 2011 for all monitored stations, corresponding with the lowest annual rainfall for the study period. The lowest annual mean salinities occurred in 2016 for all monitored stations. While 2016 did not correspond with the highest rainfall totals for the study period, it was an above average year for rainfall and included the highest rainfall recorded during January, which is typically a drier month. During 2016, instantaneous salinities were less than 35 parts per thousand (the salinity of seawater) at East River, Faka Union River, and Faka Union Boundary and were only equal to or greater than 35 parts per thousand for 0.2 percent and 2.3 percent of the record at Pumpkin River and Blackwater River, respectively. The lowest monthly mean salinities occurred at Faka Union River and East River, indicating that they received a greater amount of freshwater than the stations to the west. Rainfall-adjusted salinity monthly means had a negative trend at all stations during the study period. The slopes of the trends were slightly larger at Faka Union and East River; however, the confidence intervals for all slopes overlap, indicating that the magnitude of change in salinity is potentially equivalent between stations. The overall negative trend in salinity is likely due to the increasing trends in freshwater observed from Faka Union and East Rivers and tidal mixing, or potentially an increase in flows from outside of the locations monitored.

\section{References Cited}

Baisden, S., and Starnes, J., 2019, Picayune Strand Restoration Project facts and information: U.S. Army Corps of Engineers fact sheet, 4 p., accessed January 31, 2020, at https://usace.contentdm.oclc.org/utils/getfile/collection/ p16021 coll11/id/4175.

Booth, A.C., Soderqvist, L.E., and Berry, M.C., 2014, Flow monitoring along the western Tamiami Trail between County Road 92 and State Road 29 in support of the Comprehensive Everglades Restoration Plan, 2007-2010: U.S. Geological Survey Data Series 831, 24 p., app. A-A3 [Excel], accessed June 9, 2015, at https://dx.doi.org/10.3133/ds831.

Booth, A.C., and Soderqvist, L.E., 2016, Flow characteristics and salinity patterns of tidal rivers within the northern Ten Thousand Islands, southwest Florida, water years 2007-14: U.S. Geological Survey Scientific Investigations Report 2016-5158, 22 p., accessed April 1, 2021, at https://doi.org/10.3133/sir20165158.

Cangialosi, J.P., Latto, A.S., and Berg, R., 2017, National Hurricane Center tropical cyclone report, Hurricane Irma: National Oceanic and Atmospheric Administration [NOAA], National Weather Service, accessed April 1, 2020, at https://www.nhc.noaa.gov/data/tcr/AL112017_Irma.pdf.

Chu, F.L.E., and Volety, A.K., 1997, Disease processes of the parasite Perkinsus marinus in eastern oyster Crassostrea virginica-Minimum dose for infection initiation, and interaction of temperature, salinity and infective cell dose: Diseases of Aquatic Organisms, v. 28, p. 61-68, accessed March 8, 2021, at https://doi.org/10.3354/dao028061. 
Chuirazzi, K., Duever, M., and Abtew, W., 2015, Annual permit report for the Picayune Strand Restoration Project, phase 1-Prairie Canal backfill and road removal component: West Palm Beach, Fla., South Florida Water Management District, app. 2-1, accessed November 2015 at https://www.sfwmd.gov/portal/page/portal/pg_grp_ sfwmd_sfer/portlet_prevreport/2014_sfer/v3/appendices/ v3_app2-1.pdf.

Godin, G., 1972, The analysis of tides: Toronto, University of Toronto Press, 264 p.

Helsel, D.R., Hirsch, R.M., Ryberg, K.R., Archfield, S.A., and Gilroy, E.J., 2020, Statistical methods in water resources: U.S. Geological Survey Techniques and Methods, book 4, chap. A3, 458 p., accessed July 1, 2020, at https://doi.org/ $10.3133 / \mathrm{tm} 4 \mathrm{a} 3$.

Levesque, V.A., and Oberg, K.A., 2012, Computing discharge using the index velocity method: U.S. Geological Survey Techniques and Methods, book 3, chap. A23, 148 p. [Also available at https://doi.org/10.3133/tm3A23.]

Light, A.R., 2006, Tales of the Tamiami Trail-Implementing adaptive management in Everglades restoration: Journal of Land Use \& Environmental Law, v. 22, no. 1, p. 59-99, accessed January 11, 2021, at https://www.jstor.org/stable/ pdf/42842870.pdf?refreqid=excelsior\%3A76903fd25394 1e4a53031fe3fa5e00a9.

McCoy, J., 1972, Hydrology of western Collier County, Florida: Florida Geological Survey Report of Investigations No. 63, 32 p., accessed July 2015 at http://aquaticco mmons.org/1861/1/Collier.pdf.

Millard, S.P., 2013, EnvStats-An R package for environmental statistics: New York, Springer, accessed April 1, 2020, at https://doi.org/10.1002/9780470057339.vae043.pub2.

National Oceanic and Atmospheric Administration [NOAA], National Hurricane Center, and Central Pacific Hurricane Center, 2008, Tropical Storm Fay: National Oceanic and Atmospheric Administration [NOAA], National Hurricane Center and Central Pacific Hurricane Center web page, accessed October 1, 2019, at https://www.nhc.noaa.gov/ archive/2008/a106/a1062008.public.015.shtml.

National Oceanic and Atmospheric Administration [NOAA] and National Weather Service, 2017, 2017 mid-rainy season update: Miami-South Florida National Weather Service Forecast Office, 7 p., accessed October 22, 2020, at https://www.weather.gov/media/mfl/news/JuneJuly2017S ummary.pdf.

National Oceanic and Atmospheric Administration [NOAA], 2021, Relative sea level trends: National Oceanic and Atmospheric Administration [NOAA] web page, accessed March 8, 2021, at https://tidesandcurrents.noaa.gov/sltrends/ sltrends.html.
Pettitt, A.N., 1979, A non-parametric approach to the change point problem: Journal of the Royal Statistical Society, Series C, Applied Statistics, v. 28, no. 2, p. 126-135.

Pohlert, T., 2020, trend-Non-parametric trend tests and change-point detection $-\mathrm{R}$ package version 1.1.2: $\mathrm{R}$ Foundation for Statistical Computing, accessed April, 1, 2020, at https://CRAN.R-project.org/package=trend.

R Core Team, 2020, R-A language and environment for statistical computing: Vienna, Austria, R Foundation for Statistical Computing, accessed June 1, 2020, at https://www.R-project.org/.

Shumway, S.E., 1996, Natural environmental factors, in Kennedy, V.S., Newell, R.I.E., and Eble, A.F., eds., The eastern oyster Crassostrea virginica: College Park, Md., Maryland Sea Grant College Publication, p. 467-513.

Simpfendorfer, C.A., Wiley, T.R., and Yeiser, B.G., 2010, Improving conservation planning for an endangered sawfish using data from acoustic telemetry: Biological Conservation, v. 143, no. 6, p. 1460-1469, accessed June 9, 2016, at https://doi.org/10.1016/j.biocon.2010.03.021.

Soderqvist, L.E., and Patino, E., 2010, Seasonal and spatial distribution of freshwater flow and salinity in the Ten Thousand Islands estuary, Florida, 2007-2009: U.S. Geological Survey Data Series 501, 24 p. [Also available at https://doi.org/10.3133/ds501.]

South Florida Water Management District, 2013, Big Cypress Basin, operation of water control structures May 2013: South Florida Water Management District, accessed April 2021 at https://www.sfwmd.gov/sites/default/files/ documents/pamphlet_bcb_ops_schedule.pdf

South Florida Water Management District, 2015, Picayune pump station delivers first gallon of water for restoration: South Florida Water Management District press release, June 30, 2015, accessed November 2015 at https://www.sfwmd.gov/sites/default/files/documents/nr 2015_0630_picayune_update.pdf\#: :text $=0 \mathrm{E} 2 \% 80 \% 9$ $4 \% 20$ Rising $\% 20$ out $\% 20$ of $\% 20$ the $\% 20$ flat $\% 20$ Eve rglades $\% 20$ landscape, and $\% 20$ the $\% 20$ U.S. $\% 20$ Army $\% 20 \mathrm{Co}$ rps $\% 20$ of $\% 20$ Engineers $\% 20$ (USACE).

South Florida Water Management District, 2020, DBHYDRO menu: South Florida Water Management District database, accessed September 1, 2020, at https://www.sfwmd.gov/ science-data/dbhydro.

U.S. Army Corps of Engineers, 2008, Picayune strand restoration facts \& information: U.S. Army Corps of Engineers web page, accessed October 2008 at https://www.sfwmd.gov/sites/default/files/documents/ picayune_facts_10_2008.pdf. 
U.S. Army Corps of Engineers, 2020, Supplemental environmental assessment and finding of no significant impact Picayune Strand restoration feature, additional conveyance features and partial plugging of the Faka Union Canal: U.S. Army Corps of Engineers report, 531 p., accessed March 8, 2021, at https://hdl.handle.net/11681/36955.

U.S. Fish and Wildlife Service, 2008, Ten Thousand Islands National Wildlife Refuge: U.S. Fish and Wildlife Service fact sheet, 2 p., accessed September 2015 at https://www.fws.gov/southeast/pubs/facts/tticon.pdf.

U.S. Geological Survey, 2010, Processing and publication of discharge and stage data collected in tidally influenced areas: Office of Surface Water Technical Memorandum No. $2010.08,37$ p.

U.S. Geological Survey, 2021, USGS water data for the Nation: U.S. Geological Survey National Water Information System database, accessed June 1, 2020, at https://waterdata .usgs.gov/nwis.
Volety, A.K., Savarese, M., Hoye, B., and Loh, A.N., 2009, Landscape pattern-Present and past distribution of oysters in south Florida coastal complex (Whitewater Bay/Oyster Bay/Shark to Robert's Rivers): Fort Myers, Fla., Florida Gulf Coast University, 196 p., accessed March 8, 2021, at https://www.researchgate.net/publication/234025368_ Landscape_Pattern_Present_and_Past_Distribution_of_Oysters_in_South_Florida_Coastal_Complex_Whitewater BayOyster_BayShark_to_Robert's_Rivers.

Volety, A.K., Haynes, L., Goodman, P., and Gorman, P., 2014, Ecological condition and value of oyster reefs of the Southwest Florida shelf ecosystem: Ecological Indicators, v. 44, p. 108-119, accessed March 8, 2021, at https://doi.org/10.1016/j.ecolind.2014.03.012.

Wagner, R.J., Boulger, R.W., Jr., Oblinger, C.J., and Smith, B.A., 2006, Guidelines and standard procedures for continuous water-quality monitors - Station operation, record computation, and data reporting: U.S. Geological Survey Techniques and Methods, book 1, chap. D3, 51 p. [Also available at https://doi.org/10.3133/tm1D3.] 

For more information concerning this publication, contact

Director, Caribbean-Florida Water Science Center (CFWSC)

U.S. Geological Survey

4446 Pet Lane, Suite 108

Lutz, FL 33559

Or visit the Caribbean-Florida Water Science Center (CFWSC) website at https://www2.usgs.gov/water/caribbeanflorida/index.html

Publishing support provided by

Lafayette Publishing Service Center 


\section{$\frac{\mathbb{2}}{3}$}

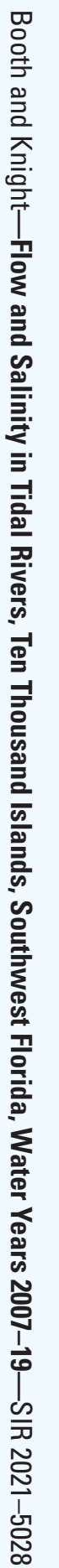

